\title{
Towards developmental modelling of tree root systems
}

\section{Tobin, B}

2007

Tobin , B , Cermak , J , Chiatante , D , Danjon , F , lorio , A D , Dupuy , L , Eshel , A , Jourdan , C , Kalliokoski , T , Laiho , R , Nadezhdina , N , Nicoll , B , Pages , L , Silva , J \& Spanos , I 2007 , ' Towards developmental modelling of tree root systems ' , Plant Biosystems , vol. 141 , no. 3 , pp. 481-501 . https://doi.org/10.1080/11263500701626283

http://hdl.handle.net/10138/33778

https://doi.org/10.1080/11263500701626283

publishedVersion

Downloaded from Helda, University of Helsinki institutional repository.

This is an electronic reprint of the original article.

This reprint may differ from the original in pagination and typographic detail.

Please cite the original version. 


\title{
Towards developmental modelling of tree root systems
}

\author{
B. TOBIN ${ }^{1}$, J. ČERMÁK ${ }^{2}$, D. CHIATANTE ${ }^{3}$, F. DANJON $^{4}$, A. DI IORIO ${ }^{3}$, L. DUPUY $^{5}$, \\ A. ESHEL ${ }^{6}$, C. JOURDAN ${ }^{7}$, T. KALLIOKOSKI ${ }^{8}$, R. LAIHO ${ }^{9}$, N. NADEZHDINA ${ }^{2}$, \\ B. NICOLL ${ }^{10}$, L. PAGÈS ${ }^{11}$, J. SILVA ${ }^{12} \&$ I. SPANOS $^{13}$ \\ ${ }^{1}$ UCD School of Biology and Environmental Science, University College Dublin, Ireland, ${ }^{2}$ Faculty of Forestry and Wood \\ Technology, Mendel University of Agriculture E Forestry, Czech Republic, ${ }^{3}$ Dipartimento di Scienze Chimiche ed Ambientali, \\ Università dell'Insubria, Italy, ${ }^{4}$ INRA, France, ${ }^{5}$ Department of Plant Sciences, University of Cambridge, UK, ${ }^{6}$ Department of \\ Plant Sciences, Tel-Aviv University, Israel, ${ }^{7}$ CIRAD, France, ${ }^{8}$ Finnish Forest Research Institute, Finland, ${ }^{9}$ University of \\ Helsinki, Department of Forest Ecology, Finland, ${ }^{10}$ Forest Research, UK, ${ }^{11}$ INRA, Centre d'Avignon, Unité PSH, France, \\ ${ }^{12}$ Centre of Applied Ecology "Prof. Baeta Neves", Portugal and ${ }^{13}$ NAGREF, Forest Research Institute, Greece
}

\begin{abstract}
Knowledge of belowground structures and processes is essential for understanding and predicting ecosystem functioning, and consequently in the development of adaptive strategies to safeguard production from trees and woody plants into the future. In the past, research has mainly been concentrated on growth models for the prediction of agronomic or forest production. Newly emerging scientific challenges, e.g. climate change and sustainable development, call for new integrated predictive methods where root systems development will become a key element for understanding global biological systems. The types of input data available from the various branches of woody root research, including biomass allocation, architecture, biomechanics, water and nutrient supply, are discussed with a view to the possibility of incorporating them into a more generic developmental model. We discuss here the main focus of root system modelling to date, including a description of simple allometric biomass models, and biomechanical stress models, and then build in complexity through static growth models towards architecture models. The next progressive and logical step in developing an inclusive developmental model that integrates these modelling approaches is discussed.
\end{abstract}

Key words: Architecture, biomass, biomechanical, developmental modeling, woody root systems

\section{Introduction}

Modelling root system straddles two major fields of research - plant development and ecosystem functioning. The emphasis and degree of detail differ between the two contexts. The individual plant models consider first biomass partitioning between above- and below-ground compartments, based on the relative sink-strength of the two parts. Further, the models describe root functioning in terms of nutrient, and water supply as well as anchorage forces. Such models help to elucidate the functional relationships between the two parts of the tree throughout its life span. They help in understanding the processes related to the develop- ment of trees on different substrates and the interrelationships within tree monocultures in orchards and plantations.

At the ecosystem level, root models describe the effect of the roots on the rhizosphere in terms of input of various organic compounds, and affected concentrations of gases such as oxygen and carbon dioxide. These models are also instrumental in the description of inter-specific competition among the forest trees. Darrah et al. (2006) provide an up to date review on rhizosphere modelling.

Many involved with ecosystem research have long deplored the lack of a truly functional dynamic model capable of describing the belowground growth and development of entire woody root systems.

Correspondence: Dr. B. Tobin, UCD School of Biology and Environmental Science, Forestry Section, Agriculture and Foodscience Centre, University College Dublin, Belfield, Dublin 4, Ireland. E-mail: brian.tobin@ucd.ie 
Knowledge of belowground structures and processes is essential for understanding and predicting ecosystem functioning (Brunner \& Godbold, 2007). Yet, this area of study has lagged behind and many structures and processes are poorly understood because of the difficulty involved in assessing them. That is why root models are, as a rule, not as advanced as aboveground growth models. For instance roots are often classified (into coarse and fine) based on diameter. However, it has been impossible to find a common classification for all purposes and species that would make sense from a functional point of view (Böhm, 1979). Root research has been motivated from a wide diversity of objectives. The aim of this paper is to summarize data types from the major areas of root research, and present the current state of root modelling. Traditionally much root research has been separated between fine roots and coarse roots, however, this paper attempts to draw together these disparate research strands to allow a greater integration which could lead to the development of more generally useful and holistic models. Indeed, models of the root system architecture (RSA) could make a bridge between the different roots (coarse and fine) and the various functions (including uptake, anchorage and carbon flux).

\section{Major areas of root research and their data needs}

Tree growth is described by Mäkelä et al. (2000) as a dynamic process where stand structures affect the distribution of the environmental driving variables in the canopy, between the trees and among the root systems, which in turn affects the amount and distribution of new growth. Progress towards process based developmental modelling will require incorporating concepts of process thinking into management models in order to make better use of empirical observations and stand system level data. Central to most modelling in this area is the acquisition of photosynthetic products and its further distribution or allocation. A brief description of a number of areas of major interest in root research will allow a greater integration of empirical, methodological and causal information.

\section{Categorization of roots in modelling}

A division of roots into different categories can be considered a practical tool to make both collection and analysis of data easier in modelling, especially when the root system to be described is as complex as the one generally produced by tree species. For this reason a definition of different categories has been attempted on the basis of differences in morphological and physiological parameters observed between roots (Pagès \& Aries, 1988; Atger \& Edelin, 1994; Jourdan \& Rey, 1997b; Waisel \& Eshel, 2002; Danjon et al., 2005). The most common division is the one distinguishing coarse from fine roots that, despite the semantic meaning of the two terms, which highlights only the occurrence of a difference in diameter, assumes that a functional difference exists i.e. with coarse roots playing a more mechanical role in plant anchorage and transport and fine roots playing a role in water and nutrient absorption. Within each one of these two broad categories it could be possible to introduce other sub-categories again on the basis of morphological and physiological differences that could be measured. As for example fine roots could be easily divided according to their growth pattern in two subcategories: one devoted to "exploration" and the other to "exploitation" (Fitter, 1985; Fitter \& Stickland, 1991). Roots of woody plants can also be classified in different root types through an architectural analysis (Atger \& Edelin, 1994, Pagès et al., 2004 - see below). The lack of a general agreement on definitions makes the inclusion of categorisation in modelling a difficult task, but it still remains a priority to be achieved if we want to improve modelling efficiency.

Apart from the difficulties of agreeing on definitions of terms, a further obstacle arises from the fact that when categories are used, it is then necessary to know the exact relationship existing between them, and hence to be included in the model. This is not a simple task as demonstrated by the fact that even for the most regularly used categorisation (coarse and fine roots), not only is the relation of one to another still not completely understood, but even the case of a fine root always remaining a fine root cannot be relied upon (Majdi et al., 2005).

\section{Biomass}

A practical consideration here is how root biomass may be regarded. It can be seen as an output; e.g. in whole-plant models biomass is produced and then partitioned between above and belowground structures according to various principles, or as an input; e.g. in root system models where it is allocated to the different classes of roots.

The adaptation of a tree species to its environment is manifested most simply in its biomass partitioning between the above- and belowground structures. The use of this arbitrary division, though based on visual perception, often causes the introduction of error because of the changing position of the soil 
surface during the life of a tree. Erosion or deposition in many forms, as well as varying stump heights, can influence what is regarded as belowground. This point is of particular importance when relating root data from different studies.

The rules that govern the course of development of tree roots are different from those that describe shoot growth and branching. The development of the roots is highly adaptable to environmental conditions and may be similar among taxonomically unrelated tree species. The critical point being that rhizosphere conditions, rather than plant type, determine root system shape and size. Therefore, general root models could be developed to describe the response of different tree species to changes in soil characteristics, including water and temperature regimes associated with climate change.

Any root-system model must take into account the specific root-shoot relationships and their variation with tree age and environmental conditions. In the latter half of the last century the number of biomass studies grew out of interest in forest resources other than stem wood (Marklund, 1988; Hakkila, 1989; Drexhage \& Gruber, 1999), and the study interests have become more diverse with the rise of ecosystem research (Peichl \& Altaf Arain, 2006; Black et al., 2007). Detailed allometric comparisons of tree crowns and root systems were required to quantify carbohydrate and nutrient flows associated with tree growth and mortality and for the parameterisation of forest growth models (Wirth et al., 2004). Modelling of the belowground structures of trees and forests is particularly important for the calculation of carbon stocks and stock changes (Brunner \& Godbold, 2007). In this instance, root biomass is of prime importance and has been the subject of much recent research, driven largely by the reporting requirements of the Kyoto Protocol and the UNFCCC (IPCC, 2003; Bert \& Danjon, 2006). Much of this research is broadly unconcerned with the spatial arrangement of this stock.

Merging data sets or comparing models from various sources is hampered by the different diameters used as the minimum diameter of "coarse roots". In earlier studies, especially, the focus was often on the exploitable wood material and the limit was quite high: $5 \mathrm{~cm}$ or simply the breakage point upon excavation (Marklund, 1988; Levy et al., 2004). Later, diameter limits of $2 \mathrm{~mm}$ (Petersson \& Ståhl, 2006), $5 \mathrm{~mm}$ (Petersson \& Ståhl, 2006) or $10 \mathrm{~mm}$ (Finér, 1989; Håland \& Brække, 1989) have been applied. Further, it is of importance whether the stump or buttressing is included or not (Nicoll et al., 1995). These components can be of major significance in the pool of total root biomass, and the mass is consequently greatly affected by the cut level.

The spatial distribution of root biomass may to varying extents be estimated non-invasively by ground penetrating radar (Butnor et al., 2003), where the extent of perturbation of the signal indicates an estimate, or by using isotope techniques (Bingham et al., 2000). The gathering of calibration and validation data describing root system structure and function poses a major stumbling block in the development of tree root-system models that describe these processes in detail. However, the analysis of root system structure will continue to be cumbersome, destructive and time demanding until newer non-destructive measurement techniques are developed for the purpose. Attempts to estimate root size have been made based on a combination of soil moisture and sap flow measurements (Čermák et al., 1980, Čermák \& Kucera, 1990). Spatial measurements of soil moisture have been shown to provide a general picture of root distribution (Biddle, 1998). Further non-invasive techniques are mentioned in the next section and in the Linking coarse and fine roots in descriptive modeling section.

\section{Architecture}

Research into architectural aspects of root systems has been carried out largely to improve silvicultural procedures, and because of concerns for forest establishment success and subsequent stability (Coutts, 1983b). The modelling of root-system architecture requires information to provide rules for the functions that describe root elongation, branching and radial growth (Coutts, 1987; Stokes et al., 1996). Furthermore, these data can subsequently provide the basis of model calibration and validation.

An overview of the most important methods used for root architecture measurements is given by Reubens et al. (in press). RSA is a result of a number of processes - branching, elongation, gravitropic response, thickening, and turnover. All aspects of the dynamics of 3D root architecture cannot generally be measured using one method, and several measurement methods are usually required (see Jourdan \& Rey 1997a). The iterative process of root branching gives rise to roots of several, so called, "orders". Each order is characterised by its own unique set of parameters that describe its frequency of branching, its elongation rate, its direction of growth, its rate of biomass deposition, and its lifespan. These in turn will determine, on one hand its functional properties in terms of anchorage, water and nutrient uptake and conductance, and on the other its influence on its 
ambient rhizosphere. It is possible also to characterise roots based on various "root types" and their associated common functioning.

The parameters included in such models are extremely difficult to measure directly in forest grown trees, and their values can usually only be derived by fitting a model to data measured on excavated tree roots. The accuracy and detail of such measurements are essential for model development. Because of the inherent variability of root systems, a large number of replicates are needed to establish the necessary reference values. Accumulating such a data set is a daunting task attempted only by the most diligent root scientists.

In the 1980 s and 1990s, most root architecture measurements in forest trees were made using the cross sectional area (CSA) method, in 2D on shallow root systems (Coutts, 1983a; Nicoll et al., 1995) and 3D (Drexhage et al., 1999). With this method the CSA and azimuth of all roots when they cross concentric cylinders are determined. The CSA method mainly provides information on the circular heterogeneity of root volume, but less information concerning branching properties. Meanwhile the properties of the roots between the cylinder walls remain unknown (Danjon, 1999c). However, it is a useful method to look at the symmetry or otherwise of a root system in relation to site or environmental conditions (Nicoll \& Ray, 1996; Ganatsas \& Spanos, 2005).

Topology and geometry measurements. The root structure is generally divided into axes, and further subdivided into segments. The limit of the segment length is determined so as to most accurately describe the structure (Danjon et al., 1999a,b).

On coarse roots, the measurement can be achieved in four ways:

- Manually using a frame and a plumb bob (e.g. Henderson et al. (1983) on $10 \mathrm{~cm}$ DBH Sitka spruce (Picea sitchensis (Bong.) Carr.), Khuder et al. (2006) on seedlings);

- Using a computer program to reconstruct the geometry from manual measurements using a rule, a compass and the inclination of the root (Dupuy et al., 2003);

- Semi-automatically using a digital compass or a 3D digitiser or (Danjon et al., 1999; Oppelt et al., 2001). Today, the most widely used method is 3D digitising with a Polhemus 3D low magnetic field digitiser, coding in the .mtg format and data checking and analysis with the AMAPmod software (e.g. Danjon et al., 1999a, 2005; Tamasi et al., 2005; Nicoll et al., 2006).

- Non-invasive techniques like by X-radiography (Pierret et al., 1999) and magnetic resonance imaging (Asseng et al., 2000), can be used to visualise the RSA. However, these two techniques can only be used on very small potted plants and have thus far not been able to provide the geometry and topology data required for architecture analysis and to date very little if any data from non-invasive methodologies have been used as modelling inputs.

Measurements can be taken both in situ (Oppelt et al., 2001; Khuder et al., 2006; Danjon et al., 2007) or on excavated root systems (e.g. Danjon et al., 1999a, 2005; Nicoll et al., 2006). The first method is generally more precise, but fairly time consuming, the second method cannot precisely record the geometry of non-rigid roots (Tamasi et al., 2005), and a certain amount of roots are lost during uprooting, though the amount of roots lost can be estimated with no extra measurements/data (Danjon et al., 2006). The range of the most commonly used digitiser has a radius of $5 \mathrm{~m}$, though longer roots can be measured either according to Danjon et al. (1999b) or according to Edwards (2003). Excavation or cleaning of the root system can be effected efficiently using high air pressure lances (Rizzo \& Gross, 2000). Coding is generally done in a format similar to the AMAPmod multi scale tree graph format (.mtg) (Godin et al., 1997; Godin \& Caraglio, 1998; Godin, 2000) or the GROGRA code (Kurth, 1994; Oppelt et al., 2001).

As 3D digitising provides a complete description of the external structure of root systems (Figure 1), it can be used to compute and model the spatial distribution of almost all parameters needed for root architecture modelling (Reubens et al., in press). Data on root architecture dynamics have been collected from chronosequences. Jourdan and Rey (1997b) measured root system characteristics in a 1-20 year-old oil palm (Elaeis guineensis Jacq.) chronosequence. Collet et al. (2006) collected data from 1-3.5 year-old Sessile oak (Quercus petraea (Matt.) Liebl.) seedlings to use in the root-typ model (Pagès et al., 2004). Collet et al. (2006) measured the topology, link length and diameter manually on whole root systems (or on a sub-sample in larger roots systems) six times a year. About 225 seedlings were measured. To get information on the spatial development of the roots, a taproot and a lateral root and all of their branches digitised in situ at the end of the experiment on four seedlings.

Fine roots were also measured by Collet et al. (2006) during the same period on four seedlings by extracting and washing soil monoliths around these seedlings. However, more precise assessments of growth dynamics can be obtained by recording the root growth in field rhizotrons (Vamerali et al., 1999), as done by Jourdan \& Rey (1997b) in oil palm trees, and by Jose et al. (2001) in walnut, oak and 


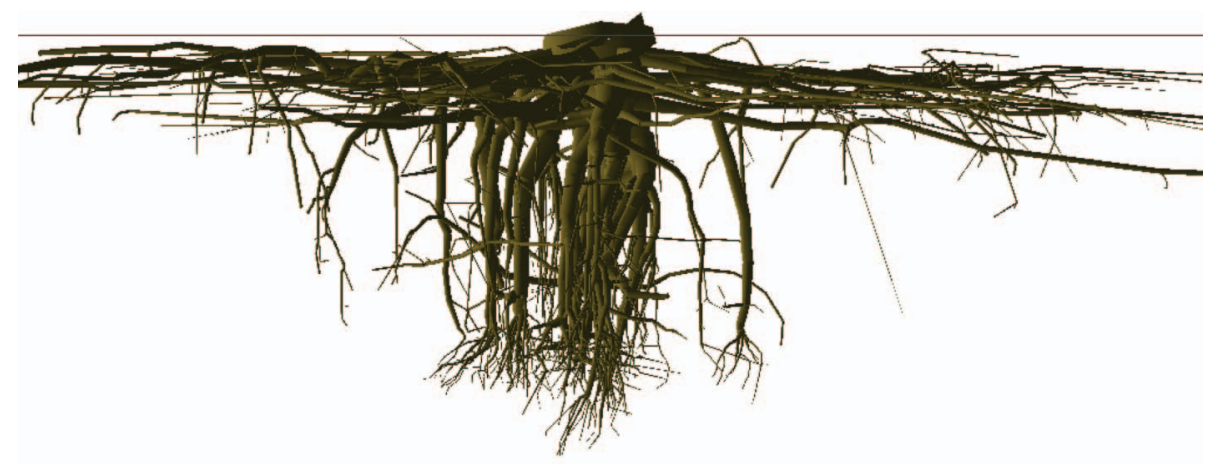

Figure 1. A graphical reconstruction from 3D digitised data of a 12-year-old Pinus pinaster root system grown in a sandy spodosol, using AMAPmod. Tree 5307 from the dataset used in Danjon et al. (2006) seen from the South with $25 \mathrm{~cm}$ collar diameter. The root system was uprooted by lifting the stump from the soil. All roots with a base diameter larger than $0.2 \mathrm{~cm}$ were measured. The solid line marks the soil level; the maximum rooting depth was $1 \mathrm{~m}$.

maize species (Vamerali et al., 2003). Minirhizotron data mainly concerns fine root turnover, providing detail on specific root lengths, longevity, growth rate, surface area (from which biomass can be inferred) and distribution.

\section{Mechanical properties of roots}

Root plate biomechanics. To predict or develop management techniques to reduce wind damage to forests, it is necessary to be able to model the mechanical behaviour of coarse roots. Most coniferous trees are supported by a system of between 3 and 11 large structural roots (Eis, 1974; Fayle, 1975; Coutts, 1983a; Kuiper \& Coutts, 1992; Mickovski \& Ennos, 2003), and on shallow rooted trees, these must develop evenly around the tree if it is to remain stable. A tree may be vulnerable to windthrow if it produces very few structural roots, or if large sectors of the root system lack such structural roots (Coutts, 1986; Danjon et al., 2005; Nicoll et al., 2006). The mechanisms by which certain roots develop into structural roots while others remain fine require further investigation, but observations of conifer root systems have shown that roots which are largest in the first years after planting often remain dominant as the tree develops (Fayle, 1975; Coutts, 1983a). However, the system is plastic, and when the soil environment changes around a tree, such as when the soil level rises, new adventitious roots or other previously small roots may become dominant (Wagg, 1967). A conceptual basis of a model of conifer root development with an emphasis on root biomechanics has been constructed by Coutts et al., (1999). It should be possible to link such a root development model to root anchorage models, such as the ones described by Blackwell et al. (1990) and Dupuy et al. (2005a), and ultimately to wind damage risk models (e.g. Peltola et al., 1999; Gardiner et al., 2004).

Roots may stretch by $10-20 \%$ of their length before failure while most soils can stretch by less than
$2 \%$. A load applied to the root system will therefore break the soil before the roots. In a study by Coutts (1986), roots broke in sequence rather than simultaneously and most roots that broke had diameters of less than $0.5 \mathrm{~cm}$. Coutts (1986) demonstrated that shallow root-soil plates are not rigid during overturning, but flexible, and that soil breaks first, under the base of the tree, with cracks propagating outwards. Most soil under shallow root plates will be broken by lifting the centre of the plate by only $2 \mathrm{~cm}$ (Ray \& Nicoll, 1998). Therefore, soil will shear under a flexible root plate with a comparatively smaller force than a rigid plate of the same area, where a larger area must shear to allow overturning to begin.

With only a small displacement needed to fracture the soil under a root-soil plate, a particularly important function of horizontal structural roots is to provide rigidity and thereby increase the force required to fracture the soil (Coutts et al., 1999). The form of the coarse root system develops, and may be modelled, through differences in the allocation of assimilates to individual roots undergoing secondary thickening (Fayle, 1975). Both the number and size of the major roots are important, as is the distribution of biomass around the tree (Nicoll et al., 1995; Coutts et al., 1999). As the stiffness of roots is approximately proportional to the fourth power of their diameter, a large number of thin coarse roots would offer considerably less resistance to bending than a few thick coarse roots with the equivalent CSA (Coutts, 1983a). However, where biomass is allocated predominantly to a small number of shallow structural roots, the effectiveness of anchorage will depend on the evenness of distribution of these roots around the stem (Coutts et al., 1999).

It must be remembered, however, that tree anchorage depends not only on the structural aspect of the root system, but also on the fine roots. Fine roots hold the soil together within the root-soil plate 
and play a large part in defining the dimensions of the plate. They consolidate the soil within the plate, increasing the mass, and they act under tension to resist breakage of the soil at the edge of, and beneath, the plate. In a similar way, fine roots hold soil on slopes and enhance soil cohesion, thereby resisting landslips and soil erosion (e.g. Reubens et al., in press). In performing these functions, fine roots depend on the whole root system being held together by a structure of coarse roots, and it will be necessary in modelling exercises to consider ways to relate coarse root architecture to fine root mass. Existing root anchorage models, such as the one described by Blackwell et al. (1990), require data including soil physical properties, root system depth, the position and stiffness of roots at the hinge point, and angles and strength of windward roots. However, in developing more sophisticated models that include rootplate flexibility, more detailed root architecture data will be required. For example a finite element modelling approach to linking root architecture, soil characteristics and tree anchorage developed by Dupuy et al. (2005a,b; Fourcaud et al., 2003) requires data on the spatial distribution of root branching, branching angles, root length, diameter and tapering.

Adaptive growth in response to mechanical stress. The effect of wind on aboveground growth and development of trees has been investigated for many years (e.g. Telewski, 1995). However, adaptive growth of roots may be even more important as an acclimative mechanism and this should be included in developmental models. In particular, these developmental responses can counteract increased movement of a tree that is poorly anchored, or particularly exposed to the prevailing wind, by allocating assimilate to parts of the tree where stress is greatest. Urban et al. (1994) reported an immediate increase in thickening of structural roots but a 4-year delay in the increase of diameter growth in the stem of White spruce (Picea glauca Voss) exposed after removal of neighbouring trees. Similar differences in timing between stem and root thickening after thinning of Red pine (Pinus resinosa Ait.) were reported by Fayle (1983), and also in an experiment where Sitka spruce trees were thinned or thinned and guyed by Nicoll \& Gardiner (2006). Danjon et al. (2005) and Khuder et al. (in press) quantitatively assessed the selective root reinforcement response to the dominant wind direction of mature Maritime pine (Pinus pinaster Ait.) trees. In both studies, only $40 \%$ of the root volume was located in sectors perpendicular to wind direction, the leeward surface roots and sinkers were thicker while the windward roots were longer and more branched. Similar biomass distribution resulting from wind stress was reported by Khuder et al. (in press). More recently, the effect of slope on root architecture and root biomass distribution has been investigated (Di Iorio et al., 2005; Chiatante \& Scippa, 2006). The authors show that trees growing on a slope develop asymmetric root architecture with lateral roots developing in two main directions: upslope and down-slope. This response seems to provide a better biomechanical anchorage of the plant to the soil. Wind and slope anchorage adaptations could be a useful implementation in root growth models.

\section{Water and nutrient relations}

Water is one of the most important natural limiting factors affecting plant growth. To reach maturity, a tree needs kilograms of mineral nutrients, thousands of kilograms of carbon, but millions of litres of water. Tree water relations are becoming more and more important in forest stands growing in unfavourable terrain and soil conditions, and when subjected to the increasing frequency of dry periods expected with global warming. Knowledge of these dynamics should be a prerequisite for any ecologically important decisions in forested regions. Both water, nutrient and energy flows can be quantitatively described and understood on the basis of a description of the surrounding environment, climate and soils and, inevitably, also of the structures where they occur i.e. the above- and belowground parts of trees and stands.

The role of root and rhizosphere modelling in this context is to describe the processes that govern the supply of water to satisfy the transpiration demand by tree crowns (Wang \& Smith, 2004). These include depth distribution of the active roots, and water movement in the soil (both gravity-related and Darcian). Root distribution is a product of the interaction between the tree species and the rooting volume characteristics. Every tree species has its own mode of root branching and elongation rates, specific root activity and response to moisture, aeration and temperature conditions. The model should account for these specific characteristics. The interaction between climate conditions, radiation, precipitation and evapotranspiration on one-hand, and soil conditions, hydraulic conductivity (both of saturated and unsaturated soil) at various layers, soil depth and slope on the other hand, determine the ambient conditions at the root surface. A model that will account for all these will be useful for investigating ecological and management questions such as forest viability at various localities or under current or hypothetical climatic scenarios.

Hagrey (2007) provides a good overview of the background, potential and some applications of geophysical imaging techniques to the study of water 
relations in trees and soils. The absorbing function of root systems and their approximate distribution have been estimated through simultaneous measurement of total tree sap flow rate, (using trunk tissue heat balance or heat field deformation methods), soil moisture and also through detailed measurements of sap flow density in different sapwood depths across stems, and interpreted in terms of water supply from roots growing at different depths (see Figure 3, Nadezhdina et al., 2007). Sensors installed in a series of sample trees can provide long-term records of diurnal and seasonal dynamics, which can be interpreted in terms of stand transpiration, impact of drought or hypoxia, vitality and functional stability. Different survival strategies of woody species can be specified and dangerous factors of environmental or of anthropogenic origin can be identified. Relatively stable forests (not jeopardized by changes of their environmental conditions) can thus be distinguished from vulnerable and unstable ones. (Figure 2 shows an example of pine and spruce behaviour under contrasting water supply in seminatural forests in central Sweden). Such information could provide an indicator of ecosystem instability and allow restorative steps to be taken.

\section{Root system depth}

Although it may be considered a particular shape variable of a root system, root depth is nevertheless an intrinsic and inevitable consideration when modelling root systems. In studies of biomass allocation, water uptake, and anchorage, it is important to consider the depth that roots may reach in the soil, and the constraints that may limit their depth. Plant root systems may reach depths of many

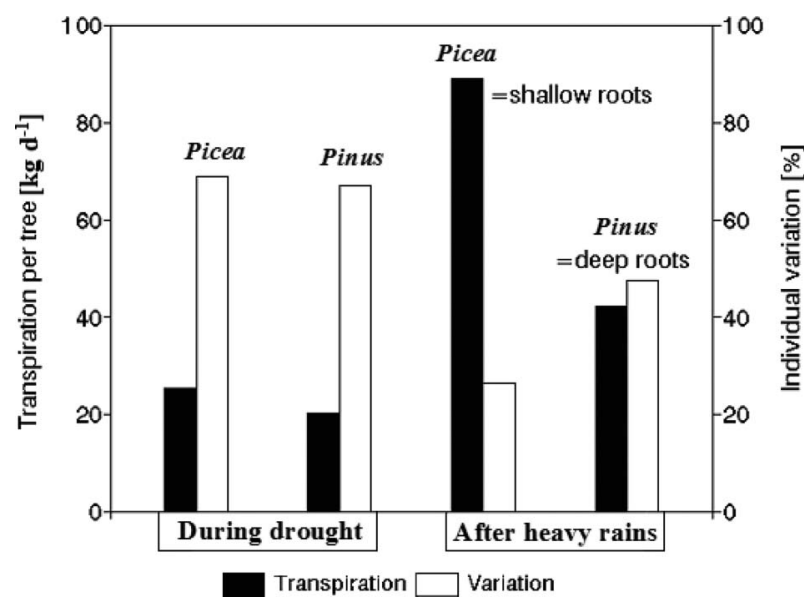

Figure 2. Transpiration rates of species with contrasting rooting depth (shallow: Picea abies, and deep: Pinus sylvestris) under changing soil moisture conditions in surface and deep soil horizons (Čermák et al., 1992). Variation between individual trees is expressed as a percentage of the mean. meters if unconstrained by soil conditions, and when a particular species is adapted to reach deep water for growth and survival during dry periods. However, root systems commonly display shallow development due to soil conditions that restrict growth. For example, in areas of high rainfall where soils have low hydraulic permeability, water tables that fluctuate close below the soil surface for much of the year are common (King et al., 1986). For most species, such conditions restrict root growth to within the aerobic soil (Kozlowski, 1982) producing particularly shallow root-soil plates (Armstrong et al., 1976) unless the water table is lowered by site drainage. Deeper roots survive if they are inactive at the time of flooding, as was shown in controlled flooding experiments by Nicoll \& Coutts (1998), who described Sitka spruce roots surviving almost $30 \mathrm{~cm}$ below a static winter water-table, with trees that had the earliest root dormancy in the autumn surviving best at deepest levels. Another common factor limiting root depth is high soil bulk density (Masle, 2002). Soils of bulk density greater than $1.6 \mathrm{~g} \mathrm{~cm}^{-3}$, and penetrometer resistance of 2.3 $\mathrm{MPa}$, are known to cause severe restriction to root growth (Day \& Bassuk, 1994) and commonly occur within $1 \mathrm{~m}$ of the soil surface on many forest sites. Without soil cultivation, tree root systems on such sites frequently remain shallow (Paterson \& Mason, 1999), and trees are particularly vulnerable to overturning in high winds.

Even in drier regions, where deep rooting is possible and necessary due to inadequate water in horizons close to the surface, deep roots represent only a small fraction of the total root system (see review by Canadell et al., 1996). The deepest roots, however, play a fundamental role in alleviating water stress during the dry season. For example, in the closed forests of Brazilian Amazonia, deep roots penetrating to $8 \mathrm{~m}$ or more may be responsible for $75 \%$ of the total water extracted during dry periods (Nepstad et al., 1994). The rooting strategy must, of course, be dictated by the requirements and life cycle of the plant and, for example, during similar developmental stages, obligate seeders develop relatively shallow root systems whereas resprouters develop deeper root systems (Keeley, 1986; Bell, 2001; Silva et al., 2003).

An important feature of tree root systems is also the distribution of absorbing roots at different depths. A sufficiently large fraction of deep roots can help trees to survive when supplying water from soil compartments less exposed to evaporational demands under drought stress. Such distribution can be derived approximately on the basis of observations that different roots are associated with different layers of stem sapwood. This means on the basis of analysis of radial patterns of sap flow, when 
sapwood depth below the cambium corresponds to a certain extent to relative rooting depth (Nadezhdina et al., 2007). This is illustrated (Figure 3) in an example of Scots pine (Pinus sylvestris L.) trees growing on sandy soil, where it was confirmed by parallel biometric measurements (Janssens et al., 1999; Xiao et al., 2003) using the traditional soil cores approach.

Maximum rooting depth therefore varies widely, according to climatic and soil conditions, and among species (Stone \& Kalisz, 1991; Canadell et al., 1996; Silva et al., 2002; Mattia et al., 2005), and the assessment of maximum rooting depth is a crucial part of coarse root studies. However, collecting root depth distribution data is not straightforward, especially for species having deep roots, which may be very difficult to access. To tackle this problem different methods have been developed. The most straightforward but laborious method is the excavation of complete root systems down to the maximum depth achieved by roots, using different digging tools, and techniques involving air pressure, water, and excavation equipment. DNA identification techniques (Linder et al., 2000) have been used to link deep roots found in caves with the respective trees found above. Modelling approaches to the prediction of root depth have been based on assessments of soil conditions, i.e. the maximum rootable depth of the soil in relation to soil compaction and aeration (e.g. Ray \& Nicoll, 1998), on allometric relationships to provide predicted maximum rooting depths based on the vertical distance to the root apex as a function of the root origin diameter (Silva \& Rego, 2003), and on statistics of root depth distribution for particular species and soils (Canadell et al., 1996; Nicoll et al., 2006).

\section{Modelling coarse root data}

\section{Modelling of biomass}

When only the biomass and/or an elemental content of the root system is of interest, allometric (statistical) models have been shown to work well. In these models, biomass is typically related to an easily measured parameter -DBH (diameter at breast height, $1.3 \mathrm{~m}$ ):

$$
\text { Biomass }=b_{1} \mathrm{DBH}^{b_{2}}
$$

or in linearized form:

$$
\begin{gathered}
\ln (\text { Biomass })=b_{0}+b_{1} \ln (\mathrm{DBH}) \\
\log (\text { Biomass })=b_{0}+b_{1} \log (\mathrm{DBH})
\end{gathered}
$$

Such models have been presented by, e.g., Marklund (1988), Finér (1989), Laiho \& Finér (1996), Drexhage \& Colin (2001) (Table I). Similarly, models for direct estimation of element contents could be developed as well, as has been done for aboveground tree parts (Laiho et al., 2003). "Fine roots" are, as a rule, not included in these models because of the difficulties in estimating their amount per tree.

Recently, Petersson \& Ståhl (2006) applied a form:

$$
\text { Biomass }=e^{\left(b_{0}+b_{1} \mathrm{DBH}\right)}
$$
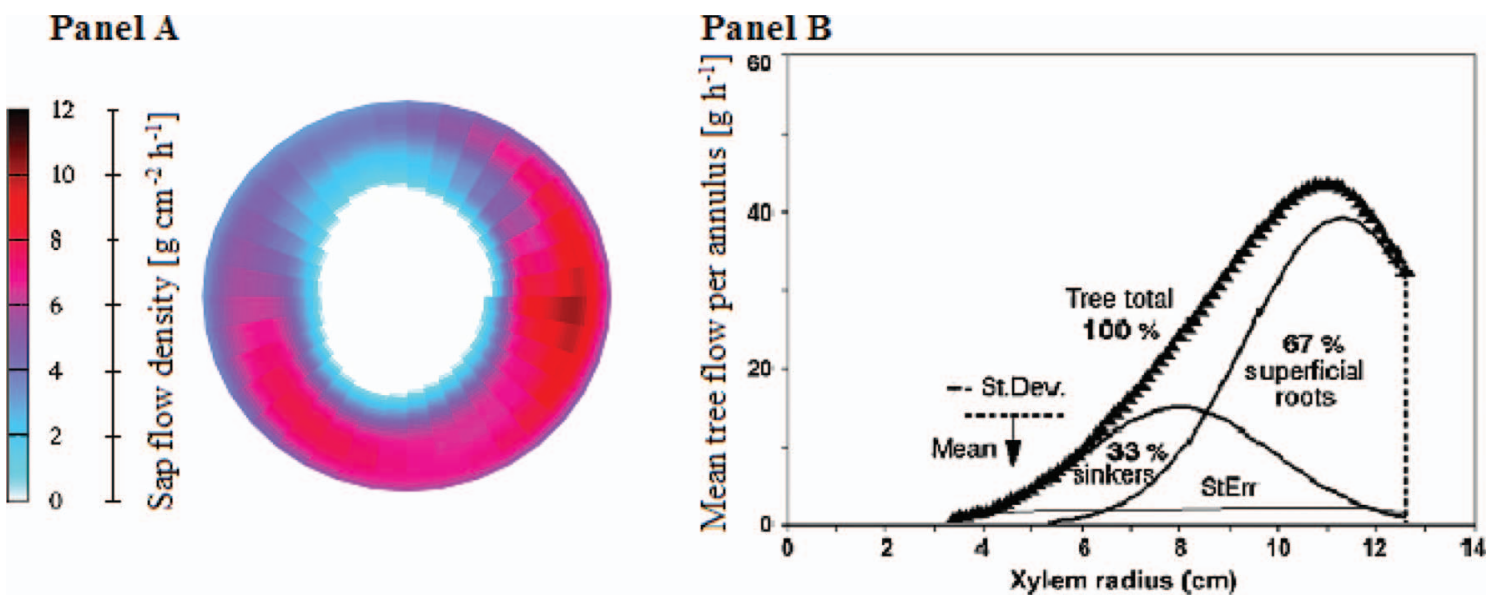

Figure 3. Panel A: Sap flow density across stem cross sections in Scots pine measured by the heat field deformation (HFD) method using 48 measuring points along the stem circumference (Čermák et al., 2004). Panel B: An interpretation of the radial pattern of sap flow from stemwood of Pinus sylvestris trees measured using HFD sensors. Sap flow in outer sapwood layers has been shown to originate more from superficial roots and flow in inner sapwood layers more from the taproot and sinker roots directly branched off the stump or from superficial roots growing several meters from the stem (Nadezhdina et al., 2007). The dotted line mean curve was measured; the curves with triangles are an interpretation of the dotted curve. An applied mathematical curve separation procedure indicates approximately the probable involvement of superficial and sinker roots in the whole-tree water supply (with large natural overlapping). 


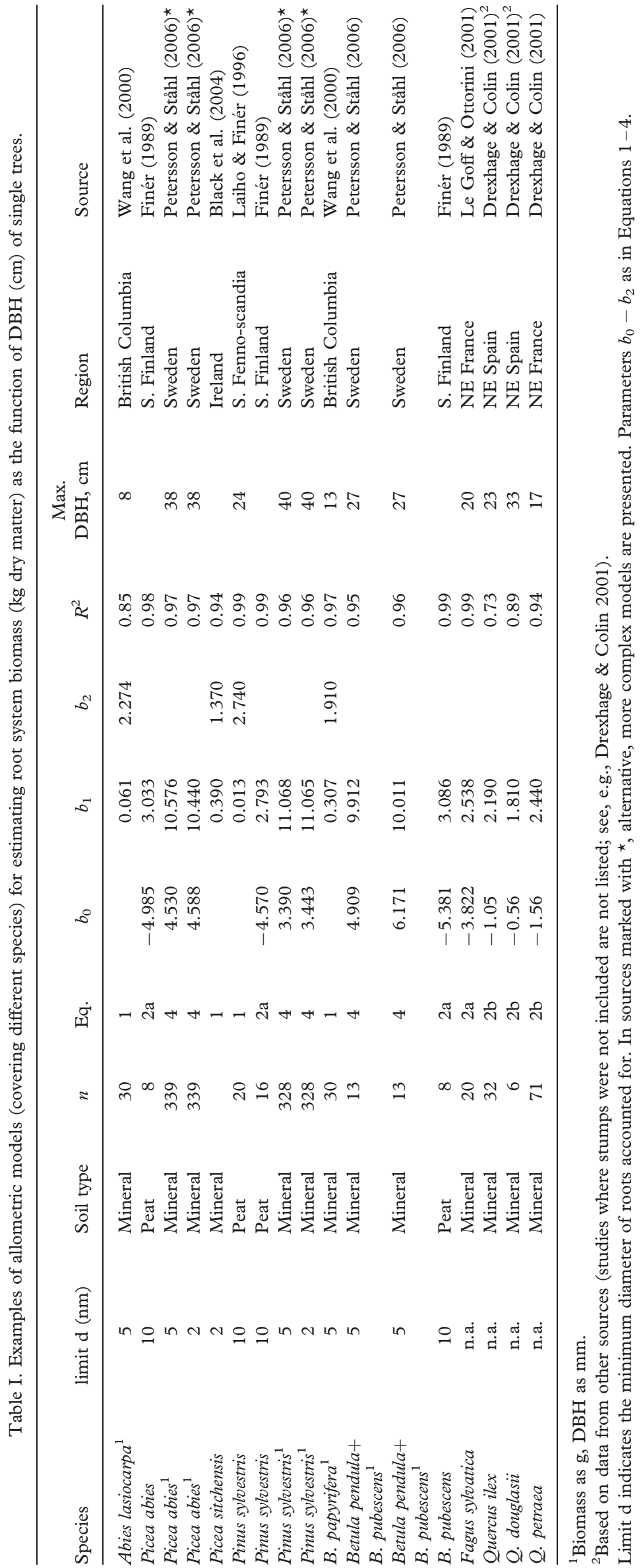


or in linearized form:

$$
\ln \text { Biomass }=b_{0}+b_{1} \mathrm{DBH}
$$

This form takes better into account that root mass is not zero when DBH is zero; however, when applied to e.g. the material used by Laiho \& Finér (1996), it overestimated the root mass of small trees, and led to a higher residual sum-of-squares. It may perform better in data sets characterized by larger trees. Depending on the range of tree $\mathrm{DBHs}$, simple linear regression may work equally well in some cases. Especially when small trees are not included, the relationship between root system biomass and $\mathrm{DBH}$ may appear to be linear (Figure 4). Thus, to avoid extrapolation errors care must be taken to ensure that the selection of sample trees produces a data set that is representative of the entire range of the diameter distribution (Wirth et al., 2004).

Such relatively simple allometric equations could be used as integrals of more complex whole-tree, ecosystem or architectural models (Modelling of root architecture section). Allometric models are speciesspecific but other parameters e.g. soil type, geographic location, climate, site quality and stand

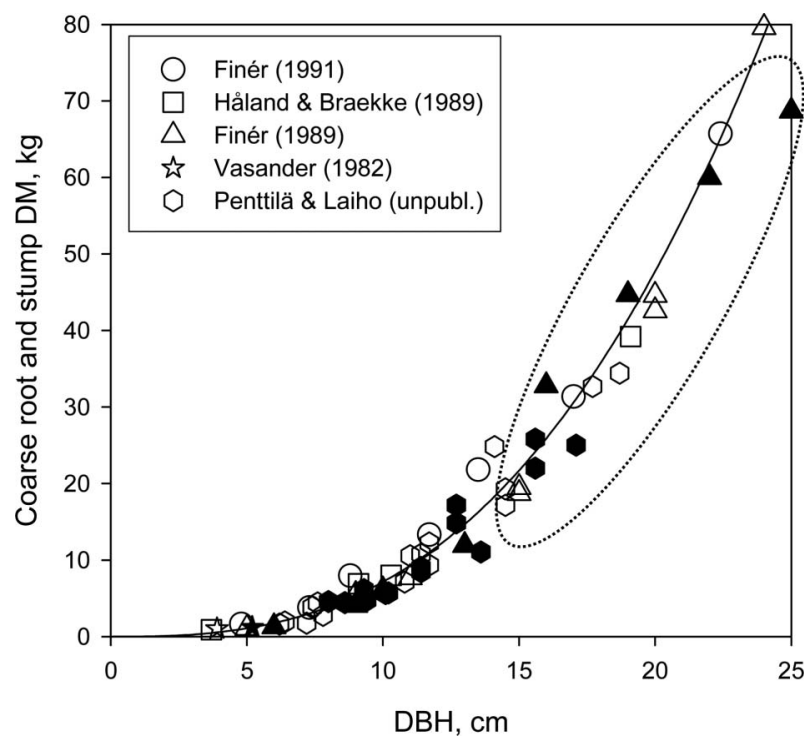

Figure 4. Single-tree root system biomass (excl. fine roots) as a function of DBH for Pinus sylvestris growing on deep peat. Data from various sources across Fennoscandia. Open symbols represent trees from drained but otherwise unmanaged stands; filled symbols represent trees from fertilized (Finér, Håland \& Braekke, Vasander) or thinned (Penttilä \& Laiho) plots. The curve shows the fit of the model $y=0.013 \mathrm{DBH}^{2.74}\left(R^{2}=0.99\right)$ developed by Laiho \& Finér (1996) using the unmanaged trees of Finér (1989, 1991), Håland \& Braekke (1989) and Vasander (1982) from southern Fennoscandia. Data of Penttilä \& Laiho are from northern Finland. If only the range of DBH values inside the dotted lines (excluding data from the small and large ends of the range) are available, simple linear regression will produce an equally good fit and the relationship would appear to be simply linear. stocking must also be considered. Minkkinen et al. (2001) compared biomass models developed for Scots pine and Norway spruce (Picea abies (L.) Karst.) growing on mineral soil (Marklund, 1988) and peat soil (Finér, 1989) and noted that the peatland models led to ca. $50 \%$ higher values (also Laiho \& Laine, 1997). Also Petersson \& Ståhl (2006) found that for fixed DBH Scots pine and Norway spruce trees, biomass increased on wetter sites. Trees growing on wet sites may need larger root systems for oxygen and nutrient uptake, or simply anchorage. In wet sites root systems remain superficial. Root system biomass has been observed to increase with decreasing rooting depth (Ray \& Nicoll, 1998), indicating a relationship between biomass and anchorage, i.e. when trees are lacking deep roots which yield better anchorage (see also Nielsen \& Hansen, 2006) further biomass is required to support more extensively ramifying surface rooting.

Petersson \& Ståhl (2006) further observed that for a fixed $\mathrm{DBH}$, biomass increased with increasing tree living crown length and stand age, but decreased with increasing tree growth rate and stand basal area. Notwithstanding, $\mathrm{DBH}$ alone is a good predictor: in the study of Petersson \& Ståhl (2006) covering the whole of Sweden, RMSE of the models decreased only a little from $31 \%-32 \%$ to $28 \%-29 \%$ when other explanatory variables were added to the models of Scots pine and Norway spruce, respectively. Most of their material came from mineral soil sites, and differences between these and organic soil sites still need further study. Table I provides examples of published allometric models for root system biomass (based on Equations 1-4). However, such standspecific functions may not always be applicable for scaling-up biomass to the regional level where several age classes and structural types coexist (Wirth et al., 2004). Yet a study based on Laiho \& Finér (1996) with additional data suggests that tree-level data from peatland sites across Fennoscandia could be covered by a single model (Figure 4 ). In such cases when the relationship of root biomass to aboveground tree parameters may be assumed to remain relatively constant irrespective of differences in stand density or age class, it might also be possible to develop functions relating total root biomass to, e.g., total stem volume (see Laiho \& Laine, 1997).

More flexibility can be introduced to biomass modelling with the development of models at single root level. Such models predict the biomass of root arborescences branching from the stump from their basal CSA (e.g. Nielsen \& Hansen, 2006). However, these models must be considered to be site or even stand specific, but can be further refined by root architectural measurements (Nielsen \& Hansen, 2006), thus approaching architectural models (see next section). 


\section{Modelling of root architecture}

Two main types of models were generally used to model root system growth, (1) static Fractal branching models which were based on fractal properties of the root parameters and (2) dynamic 3D developmental models, based on the developmental rules of the apices and incorporating soil effects on root growth.

Fractal branching models. Some of the present models rely on a fractal description (e.g. Fitter \& Stickland, 1992; Spek \& Van Noordwijk, 1994; Van Noordwijk et al., 1994; Ozier-Lafontaine et al., 1999) that uses statistical relationships between typical dimensions (e.g. length between branches, branching angles, diameters) observed locally throughout the root systems. An example of a fractal root model is FracRoot (Van Noordwijk et al., 1994; OzierLafontaine et al., 1999), based on the hypothesis that the same relationship between mother and daughter root segments holds at all levels of branching. Leonardo da Vinci was the first who proposed area-preserving branching in trees (Zimmermann, 1983). Shinozaki et al. (1964) formulated this principle in the form of the widely used pipe-model theory. Pipe-model assumptions lead to constant ratios between the successive parts in the crown. Mandelbrot (1983) asserted that the pipe-model was a special case of trees' fractal properties. Van Noordwijk et al. (1994) used Mandelbrot's idea of the self-similarity in their model, which produced theoretical root systems. Ozier-Lafontaine et al. (1999) applied the work of van Noordwijk et al. (1994) to a real tree root system and created the basic algorithm of FracRoot.

In the FracRoot model, the root system of a tree is described as a network of connected segments. A new branching order is formed in each branching event. FracRoot uses characteristics of the proximal roots (e.g. azimuth, inclination, length and diameter) and parameters estimated from sample roots as input data. By means of the input data and recursive algorithms, the model creates new segments until the final branch of the network (defined by a minimum diameter) is reached. The latest version of the FracRoot software (Salas et al., 2004) reproduces 3D-root systems, provides a visual representation and gives estimates of total length and biomass. In addition the number of root segments, length and biomass per root are given as outputs. This approach, however, is essentially static because it does not rely on morphogenetic processes, thus rendering the models nearly unable to simulate architectures bearing developmental information and/or interactions of roots with the soil.
$\mathrm{Ln} / \mathrm{Ln}$ relationships of absorbing root surface and basal area in trees of different species over a large range of tree sizes (DBH from 0.5 to $55 \mathrm{~cm}$ ) can also indicate relationships based on fractals in a root system (Čermák et al., 2006).

Developmental models. Alternatively, the approach based on development (Diggle, 1988; Pagès \& Aries, 1988; Jourdan \& Rey, 1997b) precisely formalizes and combines in a mathematical frame the main developmental rules involved in the dynamics of RSA. As applies to aboveground shoots, the root axes can generally be classified into different root types, each of them having a specific distribution of properties. Therefore, the first step of developmental root system modelling is to perform an "architectural analysis," i.e. the characterization of the different types of root axes that compose a root system, their relative layout along with their hierarchical relationships and their sequence of development (Atger \& Edelin, 1994; Jourdan \& Rey, 1997a; Pagès et al., 2004). The second step is to establish the mathematical parameters of the laws accounting for growth, mortality and branching processes for the different root types, along with their variability (Jourdan \& Rey, 1997b; Pagès et al., 2004). The third step, which could be optional, is to simulate the RSA with a model framework (simulation software) that generates 2-D or 3-D mock-ups of root systems. Various information about the distribution of parameters or of random processes (e.g. survival probability, probability to branch in a given root type) can be used to provide a stochastic output. The last step concerns a validation of the output data or images. Several validations are possible: one qualitative validation based on a visual comparison between simulations and field observations and several quantitative validations, among which: (i) comparison of root density maps both simulated and observed on trench walls, (ii) comparison of simulated and observed root biomass or specific architecture data or (iii) comparison between the parameters of the different laws arising either out of modelling, or remodelling (Jourdan \& Rey, 1997b; Pagès et al., 2004). The last validation is not often described in literature, however it aims at testing the pertinence of the mathematical laws used, and then the ability of the model itself.

The final outputs of the 3-D models, usually threedimensional mock-ups of root systems, are then used for specific applications (Jourdan \& Rey, 1997c): such as estimation of root architectural parameters for the coarse, medium or fine roots (including length, surface, volume and number of root tips), or for carbon sequestration estimation (total root biomass, necromass, fine root turnover) or for specific agronomic recommendations (such as 
modification of the planting design to avoid root competition in young stages, or fertilizer applications driven by fine root distribution).

Knowledge of the mechanisms underlying the longitudinal and radial root growth is essential for building a developmental model (Coutts et al., 1999). Longitudinal growth direction takes place through the combined effects of the positive and the negative gravitropic reactions caused by both internal and external factors (Rufelt, 1965; Coutts \& Nicoll, 1991; Nakamoto, 1994; Nakamoto \& Oyanagi, 1994; Porterfield, 2002). Internal controls are inherent in root development and also include signals from the shoot. External factors are water content (Sperry et al., 2002), nutrient composition and concentration (Clarckson, 1996), oxygen concentration (Armstrong \& Drew, 2002), pH value (Gerendás \& Ratcliffe, 2002), temperature, soil mechanical resistance (Rufelt, 1965; Coutts 1989; Masle, 2002) with which plant roots interact through processes such as gravitropism (Coutts \& Nicoll, 1991), hydrotropism (Jaffe et al., 1985; Coutts \& Nicoll, 1993; Takahashi \& Scott, 1993; Takano et al., 1995), thigmotropism (Jaffe \& Forbes, 1993; Massa \& Gilroy, 2003), oxygravitropism (Porterfield, 1998), thermotropism (Fortin \& Poff, 1990). However, there is some controversy regarding hydrotropic root behaviour in natural or field conditions. Cole \& Mahall (2006) failed to find compelling evidence of root hydrotropism in seedlings of two dune shrub species. Tsutsumi et al. $(2003,2004)$ used differential growth at the root tip level to describe root elongation. Although, it is still not clear whether the root senses the difference of water potential or the water flux, the authors assumed that the root tip senses the water flux flowing across the root cap.

Establishing the parameters of the soil properties and the mechanisms underlying root growth is another crucial aspect of RSA modelling (Darrah et al., 2006). A series of developmental models have been constructed, generally to answer specific scientific questions. Two general models for root growth were proposed by Jourdan \& Rey (1997b,c) and Pagès et al. (2004). Jourdan \& Rey (1997b,c) used a stochastic model based on the work initiated by de Reffye (1979) on shoot architecture and implemented in the AMAPsim software. The differences between the root types are taken into account setting a "physiological age" (Barthélémy et al., 1997) to the meristem at each simulation step, based on a reference axis. The root type, and therefore its initial "physiological age" at a new axis are determined from the probabilities of the mother axis to bear another root type (see Table 2 in Collet et al., 2006). This model was initially used in oil palm trees, which show no secondary thickening, it was also used in a woody plant with secondary thickening, cocoa (Theobroma cacao) (Colas, 1997). Up to now, these models do not include interactions with the soil.

Pagès et al. (2004) proposed the generic model "Root-typ", a framework incorporating most of the properties of the former developmental models and thus integrating more or less all the parameters needed to simulate root growth and soil effects on root developmental processes. In this type of model, the interactive unit is the root tip. The growth direction of each root tip is under the influence of both root tropism and soil directional constraint. Hence, at each time step, new growth direction is the resultant of the vectorial sum representing three influences: (i) previous direction, (ii) tropism, and (iii) soil directional constraint. This model was used to simulate the 3D architecture dynamics of $1-3.5$ years old Sessile oak seedlings to quantify the effects of grass competition on different development processes (Collet et al., 2006). The radial growth was modelled according to the pipe-model (Shinozaki et al., 1964). Eight main qualitative characteristics (e.g. radial growth, tropism, types of branches carried and mortality) and the mean of 12 quantitative characteristics were defined for five root types, including the taproot and fine roots. The variability was given as a standard deviation for 3 of the quantitative parameters, and used to produce stochastic outputs.

Functional structural plant models. Resource allocation to the roots and feed back from roots to the aerial parts can be driven at the whole plant scale by functional-structural plant models (FSPM, e.g. Blaise et al. 1999; Drouet and Pagès, in press). However, the root system is often only taken into account as a sink for carbohydrates. Carbohydrate partitioning to roots can be assumed to be constant or a phenologically controlled fraction of daily carbon produced, and can be controlled by e.g. water and nutrient availability, temperature (Pagès et al. 2000). Different levels of detail of a FSPM are strongly related with the aim of the model (van der Heijden et al. 2007).

Blaise et al. (1999) designed the AMAPpara FSPM model where a detailed carbon driven 3D architectural model was implemented both for shoot and roots, including the hydraulic structure, and where competition between organs is taken into account through the voxel space technique. They mainly tested the interaction between shoot and roots with regard to carbon allocation using several simple theoretical architectural models for the roots.

Drouet and Pagès (in press) designed the generic GRAAL-CN FSPM model tested on maize, where the shoot and RSAs were taken into account in the same amount of detail. The main processes 
regarding $\mathrm{C}$ and $\mathrm{N}$ management represented the organs of each system. Roots were composed of branched axes and subdivided into segments.

Density based models. Density based models demonstrate another approach to architecture modelling. Aggregated measures of the root's morphology within a unit volume of soil, i.e. root density, can alternatively be used to model root architecture. Different types of densities (e.g. biomass, volume, length, diameter or branching density) may be employed to describe any local morphological properties of roots (Danjon et al., 1999; Vercambre et al., 2003; Pierret et al., 1999), and the mapping of these densities in space and their variation in time may be used to encode information concerning entire plant structures (Dupuy et al., 2005b).

A density based approach using continuous mapping of biological properties (e.g. root length, branching) to represent root structures can be a particularly powerful method to incorporate root and soil physical interactions. It allows encoding feedbacks with the soil physical system (e.g. hydraulics, transport, mechanics) that traditionally uses continuous physical variables and equations (e.g. volume fractions, mechanical stress, soil matrix potential, solute concentrations) (Wu et al., 1988; Schnepf \& Roose, 2006).

Such approaches can be applied to build PDEs (Partial Differential Equation) of root/soil properties that integrate well with soil physics and root uptake models (Bengough, 1997; Roose \& Fowler, 2004; Wu, 2007). The research conducted by Acock \& Pachepsky (1996) and Willigen et al. (2002) have demonstrated the potential of continuous approaches to study the dynamics of plant root systems. In these studies, diffusion equations are used to predict root length density distribution in the soil.

The applicability of continuous methods to various types of crop species (e.g. maize (Zea mays), tobacco (Nicotiana spp), tomato (Lycopersicon esculentum L.) and on different external growth factors (e.g. water, fertilization, soil conditions) have been demonstrated using diffusion models (Heinen et al., 2003), however, the links between the developmental processes (elongation, branching) and the parameters of the diffusion models have not yet been addressed.

\section{Modelling root system mechanical properties}

Resistance to overtuming. Coutts (1986) and Blackwell et al. (1990) modelled the resistance of a shallow root system to overturning by separating it into four mechanically important components; weight of the root soil plate, tensile strength of the windward roots, tensile strength of the soil, and resistance to bending of roots at the hinge. The force needed to overturn the tree is this overall resistance multiplied by the length of the lever arm, that is, the distance from the tree centre to the hinge point on the root system.

As a tree starts to overturn, roots on the lee-side act mechanically as a lever-arm, while those under tension on the windward side anchor in a similar way to guy lines. The length of the lever-arm may be modelled using the position of the largest structural roots and the variation in rigidity along their length (Coutts et al., 1999). Commonly the lever-arm structural roots fail at a point where they branch. This behaviour conforms to beam-theory. If a beam is circular in cross section ( $r$ is the radius), its second moment of area, $I$, is represented by the following equation:

$$
I=\frac{\pi r^{4}}{4}
$$

The flexural stiffness of the beam is $E$ (the Young's modulus of the material) $\times I$. After a branch point, even if the combined CSA of branch roots remains the same as the 'parent' root, there is a considerable reduction in stiffness of the system, making it particularly vulnerable to failure at this point. If a 'parent' root with radius $a$ branches into two roots, each with half the CSA of the parent, and with radius $b$;

$$
I_{a}=4 I_{b}
$$

Therefore, as the two branch roots each have $0.25 \times I$ of the parent root and assuming constant Young's modulus, their combined stiffness will be half that of the parent root.

Modelling the cross-sectional shape of roots. Resistance to bending also occurs through the development of the shape of structural roots, and to be able to accurately model root bending strength, it is also necessary to describe cross sectional shape. In response to wind movement, trees with shallow structural roots have been reported to develop root cross-sectional shapes, comparable in appearance to the 'I-beams' and 'T-beams' used by engineers, to maximize resistance to bending while using a minimum of material (Büsgen \& Münch, 1929; Rigg \& Harrar, 1931). Figure 5 shows examples of these root shapes. Büsgen \& Münch (1929) proposed that the development of such shapes in tree roots results from root movement induced by stem swaying. The adaptive growth of structural roots may be analysed and modelled using a set of three descriptors of root shape (Figure 5), calculated from the dimensions of structural root cross sections: 'T-angle', 'I-angle' and $V_{\mathrm{a}} / V_{\mathrm{b}}$ ratio, (Nicoll \& Ray, 1996; Ruel et al., 2003). The T-angle describes the difference between lateral thickening in the upper and lower parts of the root 


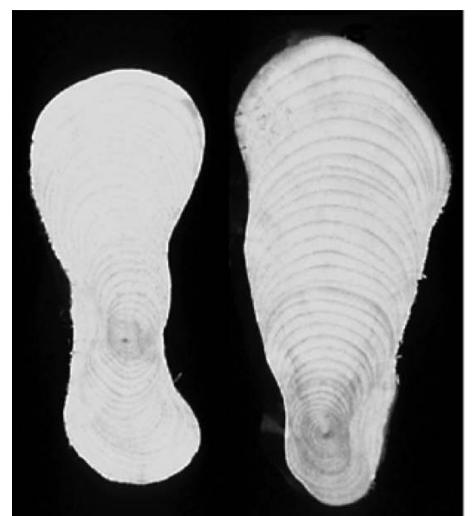

a.

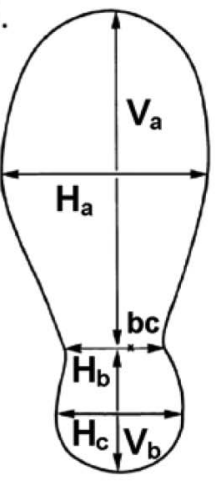

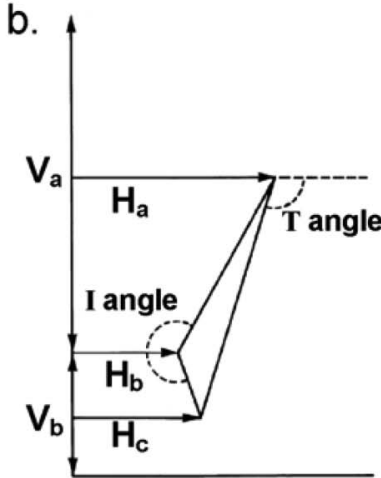

Figure 5. Analysis of root cross sectional shape. Left, Typical spruce I- and T-beam root cross sectional shapes. Right, a. A system for measurement of such sections relative to ' $b c$ ', the biological centre, and b. analysis of the development of I-beam (I angle) and T-beam shapes ( $T$ angle), from Nicoll \& Ray (1996).

section and hence the tendency towards a T-beam shape. Angles greater than $90^{\circ}$ show more lateral thickening in the upper part of the root than the lower part of the root; angles less than $90^{\circ}$ show the reverse. The further the angle deviates from $90^{\circ}$, the more T-beam shaped the section. The I-angle describes the tendency towards an I-beam shaping of the root; angles greater than $180^{\circ}$ indicate an Ibeam shape, angles less than $180^{\circ}$ indicate an ovoid shape. The $V_{\mathrm{a}} / V_{\mathrm{b}}$ ratio compares thickening in the vertical plane, above $\left(V_{\mathrm{a}}\right)$ and below $\left(V_{\mathrm{b}}\right)$ the biological centre of the root. A $V_{\mathrm{a}} / V_{\mathrm{b}}$ ratio of 1 indicates equal vertical thickening above and below the biological centre and the higher the number, the greater the upward relative to downward thickening (Nicoll \& Ray 1996; Ruel et al. 2003). To model the changes in mechanical strength along a root, the second moment of area of these shapes may be calculated as described by Nicoll (2000).

\section{Linking coarse root modelling with fine root distribution}

\section{Linking coarse and fine roots in descriptive modelling}

Descriptive modelling visualizes a root system after every root-component has interacted with macro- and micro-environmental factors during its growth. In fact, the product of modelling is the result of all the measurements of morphological (diameter, length, branching order, depth, etc.), physiological (water or nutrient absorption/transport/demand) and spatial parameters fed into the model at a certain time. This type of modelling enables the study of root system adaptation to environmental factors but cannot provide any information regarding the past or the future aspect of the root system during its developmental processes i.e. essentially a static model producing a picture of the product of a certain set of circumstances.
The aim of developmental modelling is quite different in that the description of root architecture in a particular plant species is not purely the result of any set of recorded parameters, but it represents (with a given probability) the architecture that a root system assumes at a certain time during its development i.e. the stochastic processes used by Root-typ to simulate a root system can produce a root system which does not represent the highest probability. The state of the model at every time step is the result of its previous state and its response to elapsed time and current conditions and thus provides opportunities for examining possible future scenarios.

The linking of coarse roots and fine root distribution has always been problematic because of the different scales at which each is measured. However, linkage appears broadly possible in three ways:

(1) On the basis of their spatial distribution, within a given species or between the coarse root of the studied tree species and all other fine roots. Oppelt et al. (2005a,b) digitised in 3D the coarse root system in four tropical fruit trees species and jointly measured the spatial distribution of fine roots by taking soil cores on a grid. It could be achieved at a whole stand level by using 3D digitising for coarse root measurements combined with traditional intensive fine root measurements.

(2) On the basis of the architecture, where the measurement of coarse root architecture includes information about fine roots branched from the coarse roots. Khuder et al. (2006) digitised the coarse root structure of Robinia (Robinia pseudoacacia L.) seedlings in the usual way, recording jointly in the same file the number and mean length of fine roots borne by each root segment. Establishing the topological relationship between fine and coarse has also been included in root architectural analysis (see Atger \& Edelin 1994). In one way or another, Collet et al. (2006), Vercambre et al. (2003) and Jourdan 
and Rey (1997a,b) characterized the link between fine and coarse roots and included it in their models. E.g. it was achieved in a small sample of Quercus seedlings by measuring the entire root architecture including both the fine and coarse roots (Collet et al., 2006).

(3) On the basis of an indirect measurement, the amount of fine roots on a coarse root can be gained from an examination of their functioning:

- Performing sap flow measurements on small coarse roots (Coners \& Leuschner, 2002).

- Examining radial sap flow patterns in stems and stumps (Nadezhdina et al., 2007 - see Figure 2) where a possible distribution of absorbing roots can be derived in shallow and deep soil layers.

- The magnitude of absorbing surfaces of root systems $\left(\mathrm{m}^{2}\right.$ per tree), irrespective of the tree's neighbours, may be measured by a modified electric earth impedance method (e.g. Aubrecht et al., 2006, Čermák et al., 2006). The most informative results will, it is hoped, be obtained when several methodologies can be suitably combined.

In stands, only (2 and 3) can be done on an individual tree basis.

The first (1) can be assessed partially using coring or soil monolith or trench impact counts. It could be achieved at a larger scale by using 3D digitising for coarse root measurements combined with intensive traditional fine root measurements.

One way to establish the second (2) is to $3 \mathrm{D}$ digitise the coarse root structure in the usual way, and to record the position of the fine roots on a sample of coarse roots, or the number of fine roots per segment (Khuder et al., 2006). It was also done in a small sample of Quercus seedlings by measuring the entire root architecture including both the fine and coarse roots (Collet et al., 2006).

\section{Linking coarse and fine roots in developmental modelling}

The developmental model requires a preliminary knowledge of:

- Morphological and physiological properties of the roots at different developmental stages;

- The value of the most important environmental factors characterising the site conditions where the root system develops;

- The type of interaction existing between root growth and environmental factors.

The efficiency of this theoretical modelling depends on the accuracy associated with the set of inputparameters given to the model. The importance of this type of modelling is derived from the possibility of predicting in advance the adaptation of a root system to certain environmental conditions. Roottyp (Pagès et al., 2004) represents the most advanced developmental model published so far and displays a considerable degree of accuracy in predicting the architecture developed at any stage by plants. Collet et al., (2006) demonstrated Root-typ's good predictive ability (with regard to morphological and topological aspects) using Quercus seedlings. However, it does show some deficiency when used with woody plant data. One reason for such a failure could derive from the highest degree of complexity present in woody root system, though the fact that the relationship existing between coarse and fine roots as suggested by our hypothesis has not been correctly represented in this model is also a possibility.

There is another important aspect of the relationship existing between coarse and fine root that needs to be considered because of its paramount importance for the developmental type of modelling: the number of times which the process of lateral root formation is reiterated in the life of a parental root. In other words, it is vital to include in the model the concept whether lateral roots form only during a certain phase of the development in the life span of a parental root, or whether they continue to be produced as long as the life of the parental root continues. If we assume that lateral roots arise exclusively from the tissues belonging to the primary structure present in the vascular cylinder of a parental root (Esau, 1965), then it is necessary to include in the model information on the dynamics of when primary tissue are superseded by secondary tissue, after which the possibility of producing new lateral roots should cease. E.g. in the categorisation of coarse and fine roots, the property of lateral root production should be valid for each parental root and should depend only upon tissue differentiation. However, for the case of a fine root never developing a secondary structure, once internal or external factors have induced the tissues to give origin to a new primordium for a lateral root (reviewed in Chiatante \& Scippa, 2006), the fact that the new situation has a possibility to remain a permanent property of that root should be included in a model, see Figure 6. Using the Root-typ framework, Collet et al. (2006) defined a "fine root" type with a determinate primary growth, no radial growth, no branching and short life span. In the same way, Vercambre et al. (2003) defined three non-woody root types, two of them could branch. In the model, each root type is associated with branching probabilities in all the other root types. When a root branches, the root type is defined stochastically from the probability of branching. In oil-palm trees, 


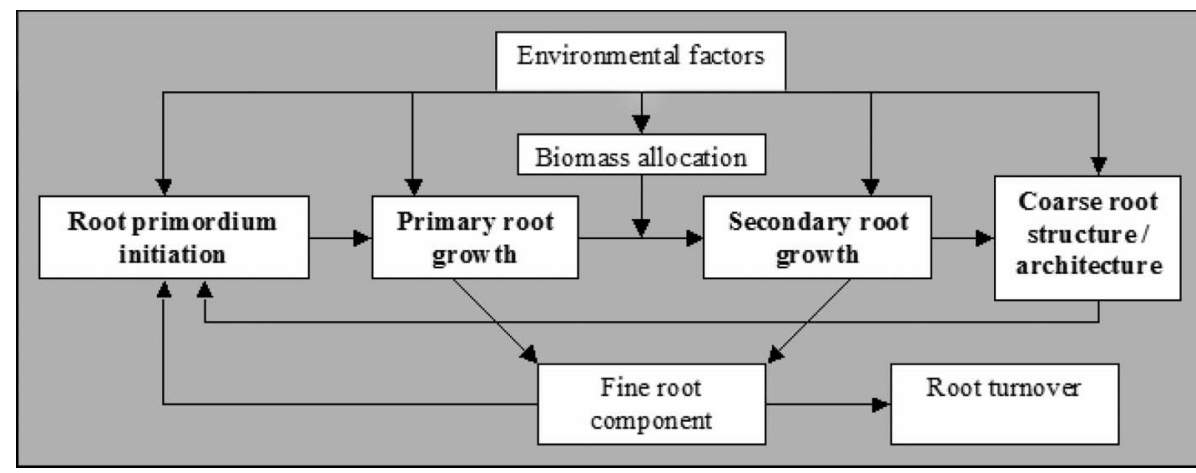

Figure 6. The link between coarse and fine root development. Modified from a conceptual model proposed by Coutts et al. (1999).

"peripheral roots" analogous to fine roots were defined, and the branching process was modelled by a Markov chain defining branching probabilities of each elementary length unit (Jourdan et al., 1995).

On the contrary, when a fine roots starts to build up a secondary structure at a certain stage of its development (i.e. at some distance from the root apex), the possibility of forming new lateral roots should be limited to the portion of its axis where primary tissues are still present. This event should be represented in the model by the fact that in the zone of a parental root with a secondary structure, the overall number of lateral roots should decrease when they are shed as a consequence of natural turnover (Chiatante \& Scippa, 2006).

Pipe model theory has been useful for root system modelling, and can provide a way for linking fine and coarse roots, in that as soon as a root carries branches, it requires additional tissues for conducting sap, and therefore it tends to become a coarse root. In the FracRoot model (Van Noordwijk et al., 1994), recursive algorithms produce new segments until the final one is limited from further growth by a minimum diameter. This could provide a useful mechanism, but for the fact that new growth would tend to allow further development. Generally, Pipe theory does not explain very well the fact that some fine roots can remain fine for their entire life. The conceptual model proposed in Figure 6 preserves this possibility while combining it in the same overall process that includes the Pipe model.

\section{Conclusions and perspectives}

Over the last decade, root research has experienced improvements in both accurate measurement techniques for the description of $3 \mathrm{D}$ root architecture, as well as refinements in generic modelling frameworks for root system growth. However, data measurement and root system growth modelling for specific applications have up to now only occasionally been made on woody root systems. Root data has often been gathered for specific purposes and cannot be used so easily for generic models. Even when large datasets on root architecture have been compiled including both topology and geometry (e.g. Danjon et al. (2004): Maritime pine on sandy spodosols), still some data (e.g. concerning root dynamics) is lacking. To acquire the appropriate data and analyse them sufficiently for entry into a modelling framework is a difficult task, which will probably not be achieved for a large number of woody species and soil conditions. However, models of root growth can be very interesting tools to test hypotheses in forestry and in agronomy or to be used in other fields such as biomechanics (Dupuy et al., 2005a) or in ecosystem functioning (Vercambre et al., 2003).

Overall, our understanding of tree above- and belowground responses to environmental influences is at a stage where useful models can be developed that integrates the various parts of the processes involved. It is evident that above- and belowground processes and responses should not be considered in isolation. Each component of a tree is dependent on a combination of the others, and an examination of the development of any component in isolation will miss a large part of the essential system. By improving our understanding of the interactions between tree components, and by integrating the models that exist of the various development processes, we will be able to make predictions of root system development, biomass and architecture in relation to species, and environment. And the consequence of every new modelling step will allow a sensitivity analysis or similar approach to identify the most important and efficient steps in the system.

Another benefit from attempting to model a complicated system is to highlight areas where research is most needed. Even before commencing the construction of a root development model, there are some areas that obviously lack adequate data. In particular it will be important to better define the relationships between the fine and coarse root architecture of woody plants, and to obtain quantitative data on the effects of climatic changes on coarse root growth and development. 
It is evident from the discussion above that tree root system models cannot be developed as a byproduct of root studies aimed at other purposes. A dedicated effort must be implemented in order to formulate a model that could be used, in conjunction with tree crown and rhizosphere models, to investigate current and future response of tree stands and forests to changing environmental conditions. Darrah et al. (2006) noted that modelling is often more limited by the difficulties in conducting experiments to generate and corroborate mechanisms rather than theoretical constraints. The data accumulated through other types of studies regarding tree physiology or performance at various sites could serve for calibration and validation of the models. However, research aimed at measuring the parameters needed in order to describe root development of various species and their response to ambient conditions must be especially planned and carried out. Coordinated collaboration of scientists from European countries using the same methods and carrying out the same type of measurements on a number of tree species will lead to formation of the necessary database for generating and testing such a model or models. Tree performance under the current range of climate conditions present across Europe may well give indications to what can be expected under future climate scenarios. Because of the complexity of the problems discussed above it may be advisable to consider not just one all-inclusive model but rather a series of models aimed at a whole range of questions such as biomass and rhizosphere interactions on one end and individual tree resistance to windthrow on the other.

\section{Acknowledgements}

The series of meetings funded by COST Action E38 "Woody Root Processes" (Working Group 3) allowed much thorough and continued discussion on the theme of woody root modelling. The authors would like to acknowledge this support that literally allowed a meeting of minds, usually pursuing very different areas of research, and an opportunity to work towards a greater understanding of the wide area of woody root processes. The authors would also like to acknowledge the considerable time and effort the reviewer devoted to this paper, contributing many useful and helpful comments.

\section{References}

Acock B, Pachepsky YA. 1996. Convective-diffusive model of twodimensional root growth and proliferation. Plant Soil 180:231-240.
Armstrong W, Booth TC, Priestley P, Read DJ. 1976. The relationship between soil aeration, stability and growth of Sitka spruce (Picea sitchensis (Bong.) Carr.) on upland peaty gleys. J Appl Ecol 13:585-591.

Armstrong W, Drew MC. 2002. Root growth and metabolism under oxygen deficiency. In: Waisel Y, Eshel A, Kafkafi U, editors. Plant roots: the hidden half. 3rd ed. New York: Marcel Dekker, Inc. pp $729-761$.

Asseng S, Aylmore LAG, McFall JS, Hopmans JW, Gregory PJ. 2000. Computer-assisted tomography and magnetic resonance imaging. In: Smit AL, Bengough AG, Engels C, Noordwijk M, Pellerin S, Geijn SC, editors. Root methods - a handbook. London: Springer. pp 343-363.

Atger C, Edelin C. 1994. Premières données sur l'architecture comparée des systèmes racinaires et caulinaires. Can J Bot 72:963-975.

Aubrecht L, Staněk Z, Koller J. 2006. Electric measurement of the absorbing surfaces in whole tree roots by the earth impedance method. I. Theory. Tree Physiol 26:1105-1112.

Barthélémy D, Caraglio Y, Costes E. 1997. Architecture, gradients morphogénétiques et âge physiologique chez les végétaux. In: Bouchon J, de Reffye P, Barthélémy D, editors. Modélisation et Simulation de L'architecture des Végétaux. INRA Editions. pp $89-136$.

Bell DT. 2001. Ecological response syndromes in the flora of southwestern Western Australia: Fire resprouters versus reseeders. Bot Rev 67:417-440.

Bengough AG. 1997. Modelling rooting depth and soil strength in a drying soil profile. J Theor Biol 186:327-338.

Bert D, Danjon F. 2006. Carbon concentration variations in the roots, stem and crown of mature Pinus pinaster (Ait.). Forest Ecol Manage 222:279-295.

Biddle P. 1998. Tree root damage to buildings: causes, diagnosis and remedy. Wantage, UK: Willowmead.

Bingham IJ, Glass ADM, Kronzucker HJ, Robinson D, Scrimgeour CM. 2000. "Isotope techniques". In: Smit AL, Bengough AG, Engels C, Noordwijk M, Pellerin S, Geijn SC, editors. Root methods - a handbook. London: Springer. pp 366-402.

Black K, Bolger T, Davis P, Nieuwenhuis M, Reidy B, Siaz G, Tobin B, Osborne B. 2007. Inventory and eddy covariancebased estimates of annual carbon sequestration in a Sitka spruce (Picea sitchensis (Bong.) Carr.) forest ecosystem. Eur J Forest Res 126:149-156.

Black K, Tobin B, Siaz G, Byrne KA, Osborne B. 2004. Allometric regressions for an improved estimate of biomass expansion factors for Ireland based on a Sitka spruce chronosequence. Irish Forest 61:50-65.

Blackwell PG, Rennols K, Coutts MP. 1990. A root anchorage model for shallowly rooted Sitka spruce. Forestry 63:73-91.

Blaise F, Fourcaud T, Stokes A, De Reffye P. 1999. A model simulating interactions between plant shoot and root architecture in a non-homogeneous environment. In: Stokes A, editor. The supporting roots of trees and woody plants: form, function and physiology Series: 'Developments in Plant and Soil Sciences', Vol. 87. Dordrecht: Kluwer Academic Publishers. pp 195-207.

Böhm W. 1979. Methods of studying root systems. New York: Springer-Verlag. 188 p.

Brunner I, Godbold DL. 2007. Tree roots in a changing world. J Forest Res 12:78-82.

Büsgen M, Münch E. 1929. The structure and life of forest trees. London: Chapman and Hall.

Butnor J, Johnsen KH, Kress L. 2003. Utility of groundpenetrating radar as a root biomass survey tool in forest systems. Soil Sci Soc Am J 67:1607-1615.

Canadell J, Jackson RB, Ehleringer JR, Mooney HA, Sala OE, Schulze E-D. 1996. Maximum rooting depth of vegetation types at the global scale. Oecologia 108:583-595. 
Čermák J, Cienciala E, Kučera J, Lindroth A, Hallgren J-E. 1992. Radial velocity profiles of water flow in stems of spruce and oak and response of spruce tree to severing. Tree Physiol 10:367380.

Čermák J, Huzulák J, Penka M. 1980. Water potential and sap flow rate in adult trees with moist and dry soil as used for the assessment of the root system depth. Biol Plant (Praha) 22:3441.

Čermák J, Kučera J. 1990. Scaling up transpiration data between trees, stands and watersheds. Silva Carelica 15:101- 120 .

Čermák J, Kučera J, Nadezhdina N. 2004. Sap flow measurements with two thermodynamic methods, flow integration within trees and scaling up from sample trees to entire forest stands. Trees-Struct Funct 18:529-546.

Čermák J, Ulrich R, Staněk Z, Koller J, Aubrecht L. 2006. Electric measurement of the absorbing surfaces in whole tree roots by the earth impedance method. II. Verification based on allometric relationships and root severing experiments. Tree Physiol 26:1113-1121.

Chiatante D, Scippa GS. 2006. Root architecture: influence of metameric organization and emission. Plant Biosyst 140:307320.

Clarckson DT. 1996. Root structure and sites of ion uptake. In: Waisel Y, Eshel A, Kafkafi U, editors. Plant roots: the hidden half. 2nd ed. New York: Marcel Dekker, Inc. pp 417-453.

Colas H. 1997. Association de cultures cocotier-cacaoyer. Modélisation de leur système racinaire. Etudes préliminaires sur l'interaction racinaire et la consommation en eau de deux plantes [Doctoral dissertation]. Université Montpellier II. $277 \mathrm{p}$.

Cole ES, Mahall BE. 2006. A test for hydrotropic behavior by roots of two coastal dune shrubs. New Phytol 172:358368.

Colin-Belgrand M, Pagès L, Dreyer E, Joannes H. 1989. Analysis and stimulation of the architecture of a growing root system: application to a comparative study of several tree seedlings. Ann Sci For 46:288-293.

Collet C, Löf M, Pagès L. 2006. Root system development of oak seedlings analysed using an architectural model. Effects of competition with grass. Plant Soil 279:367-383.

Coners H, Leuschner C. 2002. In situ water absorption by tree fine roots measured in real time using miniature sap-flow gauges. Funct Ecol 16:696-703.

Coutts MP. 1983a. Root architecture and tree stability. Plant Soil $71: 171-188$

Coutts MP. 1983b. Development of the structural root system of Sitka spruce. Forestry 56:1-16.

Coutts MP. 1986. Components of tree stability in Sitka spruce on a peaty gley soil. Forestry 59:173-197.

Coutts MP. 1987. Developmental processes in tree root systems. Can J Forest Res 17:761-767.

Coutts MP. 1989. Factors affecting the direction of growth of tree roots. In: Dreyer E, Aussenac G, Bonnet-Masimbert M, Dizengremel P, Favre JM, Garrec JP, Le Tacon F, Martin F, editors. Annales des Sciences Forestières, 46 Supplement on Forest Tree Physiology. Paris: Elsevier/INRA. pp 277-287.

Coutts MP, Nicoll BC. 1991. Orientation of the lateral roots of trees. I. Upward growth of surface roots and deflection near the soil surface. New Phytol 119:227-234.

Coutts MP, Nicoll BC. 1993. Orientation of the lateral roots of trees. II. Hydrotropic and gravitropic responses of lateral roots of Sitka spruce grown in air at different humidities. New Phytol 124:277-281.

Coutts MP, Nielsen CN, Nicoll BC. 1999. The development of symmetry, rigidity and anchorage in the structural root system of conifers. Plant Soil 217:1-15.
Danjon F. 2005. Defining root categories in Pinus pinaster (Ait) root systems, a first step for coarse root architecture modelling. Proceedings of COST E38 meeting "Woody Root Processes", 2005 June 5-9; Tartu, Estonia.

Danjon F, Barker DH, Drexhage M, Stokes A. 2007. Using 3D root architecture in models of shallow slope stability. Annals of Botany. DOI: 10.1093/aob/mcm 199.

Danjon F, Bert D, Godin C, Trichet P. 1999b. Structural root architecture of 5-year-old Pinus pinaster measured by 3D digitising and analysed with AMAPmod. Plant Soil 217: $49-63$.

Danjon F, Berthier S, Gouskou K. 2004. Root system topological and fractal branching analysis in Pinus pinaster. In: Godin C, Hanan J, Kurth W, Lacointe A, Takenaka A, Prusinkiewicz P, de Jong T, Bereridge C \& Andrieu B. editors. Proceedings of the 4th international workshop on functional-structural plant models. 2004 June 7-11; Montpellier, France. pp 75-78.

Danjon F, Drénou C, Dupuy L, Lebourgeois F. 2006. Racines, sol et mécanique de l'ancrage de l'arbre [Soil, roots and anchorage mechanics of the tree]. In: Forêt, vent risques. Gip Ecofor/ QUAE Editeur.

Danjon F, Fourcaud T, Bert D. 2005. Root architecture and windfirmness of mature Pinus pinaster (Ait.). New Phytol 168:387-400.

Danjon F, Pagès L, Descorps MC. 2006. Root diameter as predictor of borne root volume. Estimating the missing root characteristics in Pinus pinaster (Ait) root systems. Proceedings of COST E38 meeting, Sede Boqer, 2006 Feb 4-8; Israel [poster].

Danjon F, Sinoquet H, Godin C, Colin F, Drexhage M. 1999. Characterization of structural tree root architecture using 3D digitizing and AMAPmod software. Plant Soil 211:241258.

Darrah P, Jones D, Kirk G, Roose T. 2006. Modelling the rhizosphere: a review of methods for "upscaling" to the whole plant scale. Eur J Soil Sci 57:13-25.

Day SD, Bassuk NL. 1994. A review of the effects of soil compaction and amelioration treatments on landscape trees. J Arboriculture 20:9-17.

Di Iorio A, Lasserre B, Scippa GS, Chiatante D. 2005. Root system architecture of Quercus pubescens trees growing on different sloping conditions. Ann Bot (Lond) 95:351-361.

Diggle AJ. 1988. ROOTMAP - a model in three-dimensional coordinates of the growth and structure of fibrous root systems. Plant Soil 105:169-178.

Drexhage M, Chauvière M, Colin F, Nielsen CNN. 1999. Development of structural root architecture and allometry of Quercus petraea. Can J Forest Res 29:600-608.

Drexhage M, Colin F. 2001. Estimating root system biomass from breast-height diameters. Forestry 74: 491-497.

Drexhage M, Gruber F. 1999. Above- and below-stump relationships for Picea abies: estimating root system biomass from breast height diameters. Scand J Forest Res 14:328-333.

Drouet J-L, Pagès L. In press. GRAAL-CN: a model of growth, architecture and allocation for carbon and nitrogen dynamics within whole plants formalised at the organ level. Ecol Model. 206:231 - 249.

Dupuy L, Drénou C, Fourcaud T. 2003. Sols, racines et ancrage des arbres forestiers. Forêt Entreprise 15:39-43.

Dupuy L, Fourcaud T, Stokes A. 2005a. A numerical investigation into the influence of soil type and root architecture on tree anchorage. Plant Soil 278:119-134.

Dupuy L, Fourcaud T, Stokes A, Danjon F. 2005b. A densitybased approach for the modelling of root architecture: application to Maritime pine (Pinus pinaster Ait.) root systems. J Theor Biol 236:323-334.

Eis S. 1974. Root system morphology of western hemlock, western red cedar, and Douglas fir. Can J Forest Res 4:28-38. 
Edwards JG. 2003. Field based 3D digitising of woody root architecture - techniques and results. Proceedings of 3rd International Symposium on Dynamics of Physiological Processes in Woody Roots, 2003 Sept 28-Oct 3; Perth, Australia. p 36.

Esau K. 1965. Plant anatomy. 2nd edition. New York: Wiley.

Fayle DCF. 1975. Distribution of radial growth during the development of Red pine root systems. Can J Forest Res 5:608-625.

Fayle DCF. 1983. Differences between stem and root thickening at their junction in red pine. Plant Soil 71:161-166.

Finér L. 1989. Biomass and nutrient cycle in fertilized and unfertilized pine, mixed birch and pine and spruce stands on a drained mire. Acta Forestalia Fennica 208:1 - 63 .

Fitter AH. 1985. Functional significance of root morphology and root system architecture. In: Fitter AH, Atkinson D, Read DJ, Usher MB, editors. Ecological interactions in soil, Special Publication of the British Ecological Society, No. 4. Oxford: Blackwell. pp 87-106.

Fitter AH, Stickland TR. 1991. Architectural analysis of plant root systems 2. Influence of nutrient supply on architecture in contrasting plant species. New Phytol 118:383-389.

Fitter AH, Stickland TR. 1992. Fractal characterization of root system architecture. Funct Ecol 6:632-635.

Fortin MA, Poff KL. 1990. Temperature sensing by primary roots of maize. Plant Physiol 9:637-639.

Fourcaud T, Blaise F, Lac P, Castéra P, de Reffye P. 2003. Numerical modelling of shape regulation and growth stresses in trees. II. Implementation in the AMAPpara software and simulation of tree growth. Trees 17:31-39.

Ganatsas P, Spanos I. 2005. Root system asymmetry of Mediterranean pines: an ecological adaptation to overcome summer drought. Plant Soil 278:75-83.

Gardiner B, Suarez J, Achim A, Hale S, Nicoll B. 2004. ForestGALES. A PC-based wind risk model for British forests. Version 2.0. Forestry Commission, Edinburgh.

Gerendás J, Ratcliffe RG. 2002. Root pH regulation. In: Waisel Y, Eshel A, Kafkafi U, editors. Plant roots: the hidden half. 3rd ed. New York: Marcel Dekker, Inc. pp 553-570.

Godin C. 2000. Representing and encoding plant architecture: a review. Ann For Sci 57:413-438.

Godin C, Caraglio Y. 1998. A multiscale model of plant topological structures. J Theor Biol 191:1-46.

Godin C, Costes E, Caraglio Y. 1997. Exploring plant topological structure with the AMAPmod software: an outline. Silva Fenn 31:355-366.

Hakkila P. 1989. Utilization of residual forest biomass. Berlin: Springer Verlag. 568 p.

Håland B, Brække FH. 1989. Distribution of root biomass in a low-shrub pine bog. Scand J Forest Res 4:307-316.

Hagrey SA. 2007. Geophysical imaging of root-zone, trunk, and moisture heterogeneity. J Exp Bot 58, 839-854.

Heinen M, Mollier A, De Willigen P. 2003. Growth of a root system described as diffusion. II. Numerical model and application. Plant Soil 252:251-265.

Henderson R, Ford ED, Renshaw E. 1983. Morphology of the structural root system of Sitka spruce 2. Computer simulation of rooting pattern. Forestry 56:137-153.

IPCC. 2003. Good practice guidance for Land use, Land-use Change and Forestry. IPCC National Greenhouse Gas Inventories Programme, Hayama, Japan.

Jaffe MJ, Forbes S. 1993. Thigmomorphogenesis, the effect of mechanical perturbation on plants. Plant Growth Regul 12:313-324.

Jaffe MJ, Takahashi H, Biro RL. 1985. A pea mutant for the study of hydrotropism in roots. Science 230: 445-447.

Janssens IA, Sampson DA, Čermák J, Meiresonne L, Riguzzi F, Overloop S, Ceulemans R. 1999. Above- and belowground phytomass and carbon storage in a Belgian Scots pine stand. Ann Forest Sci 56:81-90.
Jose S, Gillespie A, Seifert J, Pope P. 2001. Comparison of minirhizotron and soil core methods for quantifying root biomass in a temperate alley cropping system. Agroforest Syst 52:161-168.

Jourdan C, Rey H. 1997a. Architecture and development of the oil-palm (Elaeis guineensis Jacq.) root system. Plant Soil 189:33-48.

Jourdan C, Rey H. 1997b. Modelling and simulation of the architecture and development of the oil-palm (Elaeis guineensis Jacq.) root system. I. The model. Plant Soil 190:217-233.

Jourdan C, Rey H. 1997c. Modelling and simulation of the architecture and development of the oil-palm (Elaeis guineensis Jacq.) root system. II. Estimation of root parameters using the RACINES postprocessor. Plant Soil 190:235-246.

Jourdan C, Rey H, Guédon Y. 1995. Architectural analysis and modelling of the branching process of the young oil-palm root system. Plant Soil 177:63-72.

Keeley JE. 1986. Resilience of Mediterranean shrub communities to fires. In: Dell A, Hopkins JM, Lamont BB, editors. Resilience in Mediterranean-type ecosystems. Dordrecht: Dr W. Junk Publishers. pp 95-112.

Khuder H, Danjon F, Stokes A, Fourcaud F. 2006. Growth response and root architecture of black locust seedlings growing on slopes and subjected to mechanical perturbation. Proceedings of 5th Plant Biomechanics Conference; 2006 Aug 28-Sept 1; Stockholm.

Khuder H, Stokes A, Danjon F, Gouskou K, Lagane F. 2007. Is it possible to manipulate root anchorage in young trees. Plant \& Soil. 294:87 - 102 \& erratum Plant \& Soil (2007) 295:293-295.

King JA, Smith KA, Pyatt DG. 1986. Water and oxygen regimes under conifer plantations and native vegetation on upland peaty gley soil and deep peat soils. J Soil Sci 37:485-497.

Kozlowski TT. 1982. Water supply and tree growth, Part II. Flooding. Forestry Abst 43:145-161.

Kuiper LC, Coutts MP. 1992. Spatial disposition and extension of the structural root system of Douglas-fir. For Ecol Manage 47:111- 125 .

Kurth W. 1994. Growth grammar interpreter GROGRA 2.4 Berichte des Forschungszentrum Waldökosysteme, Vol. B. Universität Göttingen. 192 p.

Laiho R, Finér L. 1996. Changes in root biomass after water-level drawdown on pine mires in southern Finland. Scand J Forest Res 11:251-260.

Laiho R, Laine J. 1997. Tree stand biomass and carbon content in an age sequence of drained pine mires in southern Finland. For Ecol Manage 93:161-169.

Laiho R, Vasander H, Penttilä T, Laine J. 2003. Dynamics of plant-mediated organic matter and nutrient cycling following water-level drawdown in boreal peatlands. Global Biogeochem Cy 17:1053, DOI:10.1029/2002GB002015.

Le Goff N, Ottorini J-M. 2001. Root biomass and biomass increment in a beech (Fagus sylvatica L.) stand in North-East France. Ann For Sci 58:1-13.

Levy PE, Hale SE, Nicoll BC. 2004. Biomass expansion factors and root:shoot ratios for coniferous tree species in Great Britain. Forestry 77:421 -430.

Linder C, Moore L, Jackson R. 2000. A universal molecular method for identifying underground plant parts to species. Mol Ecol 9:1549-1559.

Majdi H, Pregitzer K, Morén A-S, Nylund J-E, Ågren GI. 2005. Measuring fine root turnover in forest ecosystems. Plant Soil 276:1-8.

Mäkelä A, Landsberg J, Ek A, Burk T, Ter-Mikaelian M, Ågren G, Oliver C, Puttonen P. 2000. Process-based models for forest ecosystem management: current state of the art and challenges for practical implementation. Tree Physiol 20:289298. 
Mandelbrot BB. 1983. The fractal geometry of nature. York, USA: Freeman. 468 p.

Marklund LG. 1988. Biomassafunktioner för tall, gran och björk i Sverige. Summary: biomass functions for pine, spruce and birch in Sweden. Sveriges lantbruksuniversitetet, institutionen för skogstaxering, Rapport 45 . Umeå. $73 \mathrm{p}$.

Masle J. 2002. High soil strength: mechanical forces at play on root morphogenesis and in root:shoot signaling. In: Waisel Y, Eshel A, Kafkafi U, editors. Plant roots: the hidden half. 3rd ed. New York: Marcel Dekker, Inc. pp 807-819.

Massa GD, Gilroy S. 2003. Touch modulates gravity sensing to regulate the growth of primary roots of Arabidopsis thaliana. Plant J 33:435-445.

Mattia C, Bischetti BG, Gentile F. 2005. Biotechnical characteristics of root systems of typical Mediterranean species. Plant Soil 278:23-32.

Mickovski SB, Ennos AR. 2003. Anchorage and asymmetry in the root system of Pinus peuce. Silva Fenn 37:161-173.

Minkkinen K, Laine J, Hökkä H. 2001. Tree stand development and carbon sequestration in drained peatland stands in Finland-a simulation study. Silva Fenn 35:55-69.

Nadezhdina N, Čermák J, Meiresonne L, Ceulemans R. 2007. Transpiration of Scots pine in Flanders growing on soil with irregular substratum. For Ecol Man 243:1-9.

Nakamoto T. 1994. Plagiogravitropism of maize roots. Plant Soil 165:327-332.

Nakamoto T, Oyanagi A. 1994. The direction of growth of seminal roots of Triticum aestivum $\mathrm{L}$. and experimental modification thereof. Ann Bot-London 73:363-367.

Nepstad DC, Carvalho CR, Davidson EA, Jipp PH, Lefebvre PA, Negreiros GH, Silva E, Stone TA, Trumbore SE, Vieira S. 1994. The role of deep roots in the hydrological and carbon cycles of Amazonian forests and pastures. Nature 372:666669.

Nicoll BC. 2000. The mechanical consequences of adaptive growth in roots. In: Spatz H-C, Speck T, editors. Plant biomechanics 2000. Freiburg - Badenweiler: Thieme. pp $213-216$.

Nicoll BC, Berthier S, Achim A, Gouskou K, Danjon F, van Beek LPH. 2006. The architecture of Picea sitchensis structural root systems on horizontal and sloping terrain. Trees-Struct Funct 20:701-712.

Nicoll BC, Coutts MP. 1998. Timing of root dormancy and tolerance to root waterlogging in clonal Sitka spruce. Trees Struct Funct 12:241-245.

Nicoll BC, Easton EP, Milner AD, Walker C, Coutts MP. 1995. Wind stability factors in tree selection: distribution of biomass within root systems of Sitka spruce clones. In: Coutts MP, Grace J, editors. Wind and trees. Cambridge: Cambridge University Press. pp 276-292.

Nicoll BC, Gardiner BA. 2006. The effects of increased wind action on the radial growth of tree stems and structural roots. In: Salmén L, editor. Proceedings of the 5th Plant Biomechanics Conference. 2006 Aug 28-Sept 1; Stockholm. pp 281-286.

Nicoll BC, Ray D. 1996. Adaptive growth of tree root systems in response to wind action and site conditions. Tree Physiol 16:899-904.

Nielsen CCN, Hansen JK. 2006. Root CSA-root biomass prediction models in six tree species and improvement of models by inclusion of root architectural paramenters. Plant Soil 280:339-356.

Oppelt AL, Kurth W, Dzierzon H, Jentschke G, Godbold DL. 2000. Structure and fractal dimensions of root systems of four co-occurring fruit tree species from Botswana. Ann Forest Sci $57: 463-475$.

Oppelt AL, Kurth W, Godbold DL. 2001. Topology, scaling relations and Leonardo's rule in root systems from African tree species. Tree Physiol 21:117-128.
Oppelt AL, Kurth W, Godbold DL. 2005a. Contrasting rooting patterns of some arid-zone fruit tree species from Botswana. II. Coarse root distribution. Agroforest Syst 64:13-24.

Oppelt AL, Kurth W, Jentschke G. 2005b. Contrasting rooting patterns of some arid-zone fruit tree species from Botswana. I. Fine root distribution. Agroforest Syst 64:1-11.

Ozier-Lafontaine H, Lecompte F, Sillon JF. 1999. Fractal analysis of the root architecture of Gliricidia sepium for the spatial prediction of root branching, size, and mass. Model development and evaluation in agroforestry. Plant Soil 209:167-180.

Pagès L, Aries F. 1988. SARAH: modèle de simulation de la croissance, du développement, et de l'architecture des systèmes racinaires. Agronomie 8:889-896.

Pagès L, Asseng S, Pellerin S, Diggle A. 2000. Modelling root system growth and architecture. In: Smit AL, Bengough AG, Engels C, Noordwijk M, Pellerin S, Geijn SC, editors. Root methods - a handbook. London: Springer. pp 113-146.

Pagès L, Vercambre G, Drouet J-L, Lecompte F, Collet C, Le Bot J. 2004. Root type: a generic model to depict and analyse the root system architecture. Plant Soil 258:103-119.

Paterson DB, Mason WL. 1999. Cultivation of soils for forestry. Forestry Commission Bulletin 119. Edinburgh: Forestry Commission.

Peichl M, Altaf Arain M. 2006. Above- and belowground ecosystem biomass and carbon pools in an age-sequence of temperate pine plantation forests. Agr Forest Meteorol 140:51-63.

Peltola H, Kellomäki S, Väisänen H, Ikonen V-P. 1999. A mechanistic model for assessing the risk of wind and snow damage to single trees and stands of Scots pine, Norway spruce, and birch. Can J Forest Res 29:647-661.

Petersson H, Ståhl G. 2006. Functions for belowground biomass of Pinus sylvestris, Picea abies, Betula pendula and Betula pubescens in Sweden. Scand J Forest Res 21(S7):84-93.

Pierret A, Capowiez Y, Moran CJ, Kretzschmar A. 1999. X-ray computed tomography to quantify tree rooting spatial distributions. GEODERMA 90:307-326.

Porterfield DM. 2002. Environmental sensing and directional growth of plant roots. In: Waisel Y, Eshel A, Kafkafi U, editors. Plant roots: the hidden half. 3rd ed. New York: Marcel Dekker, Inc. pp 471-487.

Porterfield DN. 1998. The tropic response of plant roots to oxygen: oxytropism in Pisum sativum L. Planta 206:1-6.

Ray D, Nicoll B. 1998. The effect of soil water-table depth on root-plate development and stability of Sitka spruce. Forestry $71: 169-182$

Reffye P de. 1979. Modélisation de l'architecture des arbres par des processus stochastiques. Simulation spatiale des modèles tropicaux sous l'effet de la pesanteur. Application au Coffea robusta [Doctoral disertation]. University Paris-Sud Centre d'Orsay. 195 p.

Reubens B, Poesen J, Danjon F, Geudens G, Muys B. 2007. The role of fine and coarse roots in shallow slope stability and soil erosion control with a focus on root system architecture: a review. Trees Struct Funct. 21:385-402.

Rigg GB, Harrar ES. 1931. The root systems of trees growing in sphagnum. Am J Bot 18:391-397.

Rizzo DM, Gross R. 2000. Distribution of armillaria on pear root systems and a comparison of root excavation techniques. In: Stokes A, editor. Proceedings of "The Supporting Roots of Trees and Woody Plants: Form, Function and Physiology". 1998 July 20-24; Bordeaux. Series: 'Developments in Plant and Soil Sciences', Vol. 87. Dordrecht: Kluwer Academic Publishers. pp $61-76$

Roose T, Fowler AC. 2004. A mathematical model for water and nutrient uptake by plant root systems. J Theor Biol 228: 173-184.

Ruel J-C, Larouche C, Achim A. 2003. Changes in root morphology after precommercial thinning in balsam fir stands. Can J Forest Res 33:2452-2459. 
Rufelt H. 1965. Plagiogeotropism in roots. Encyclopedia of plant physiology Vol. 17. Berlin: Springer Verlag. pp 322-343.

Salas E, Ozier-Lafontaine H, Nygren P. 2004. A fractal model applied for estimating root biomass and architecture in two tropical legume tree species. Ann Forest Sci 61:337-345.

Schnepf A, Roose T. 2006. Modelling the contribution of arbuscular mycorrhizal fungi to plant phosphate uptake. New Phytol 171:669-682.

Shinozaki K, Yoda K, Hozumi K, Kira T. 1964. A quantitative analysis of plant form - The Pipe Model Theory: I. Basic Analysis. Jap J Ecol 14:97-105.

Silva JS, Rego FC. 2003. Root distribution of a Mediterranean shrubland in Portugal. Plant Soil 255:529-540.

Silva JS, Rego FC, Martins-Loução MA. 2002. Belowground traits of Mediterranean woody plants in a Portuguese shrubland. Ecol Medit 28:5-13.

Silva JS, Rego FC, Martins-Loução MA. 2003. Root distribution of Mediterranean woody plants: introducing a new empirical model. Plant Biosyst 137:63-72.

Spek LY, Van Noordwijk M. 1994. Proximal root diameters as predictors of total root system size for fractal branching models. II. Numerical model. Plant Soil 164:119-128.

Sperry JS, Stiller V, Hacke UG. 2002. Soil water uptake and water transport through root systems. In: Waisel Y, Eshel A, Kafkafi U, editors. Plant roots: the hidden half. 3rd ed. New York: Marcel Dekker, Inc. pp 663-681.

Stokes A, Ball J, Fitter AH, Brain P, Coutts MP. 1996. An experimental investigation of the resistance of model root systems to uprooting. Ann Bot-London 78:415-421.

Stone EL, Kalisz PJ. 1991. On the maximum extent of tree roots. Forest Ecol Manage 46:59-102.

Takahashi H, Scott TK. 1993. Intensity of hydrostimulation for the induction of root hydrotropism and its sensing by the root cap. Plant Cell Environ 16:99-103.

Takano M, Takahashi H, Hirasawa T, Suge H. 1995. Hydrotropism in roots: sensing of a gradient in water potential by the root cap. Planta 197:410-413.

Tamasi E, Stokes A, Lasserre B, Danjon F, Berthier S, Fourcaud T, Chiatante D. 2005. Influence of wind loading on root system development and architecture in oak (Quercus robur L.) seedlings. Trees Struct Funct 19:374-384.

Telewski FW. 1995. Wind-induced physiological and developmental responses in trees. In: Coutts MP, Grace J, editors. Wind and Trees. Cambridge: Cambridge University Press. pp $237-263$.

Tsutsumi D, Kosugi K, Mizuyama T. 2003. Root-system development and water-extraction model considering hydrotropism. Soil Sci Soc Am J 67:387-401.

Tsutsumi D, Kosugi K, Mizuyama T. 2004. Three-dimensional modeling of hydrotropism effects on plant root architecture along a hillslope. Vadose Zone J 3:1017-1030.

Urban ST, Lieffers VJ, MacDonald SE. 1994. Release in radial growth in the trunk and structural roots of white spruce as measured by dendrochronology. Can J Forest Res 24:15501556.
Vamerali T, Ganis A, Bona S, Mosca G. 1999. An approach to minirhizotron root image analysis. Plant Soil 217:183-193.

Vamerali T, Ganis A, Bona S, Mosca G. 2003. Fibrous root turnover and growth in sugar beet (Beta vulgaris var. saccharifera) as affected by nitrogen shortage. Plant Soil 255:169-177.

van der Heijden G, de Visser P, Heuvelink E. 2007. Measurements for functional-structural plant models. In: Vos J, editor. Functional-structural plant modelling in crop production series: Wageningen UR Frontis Series, Vol. 22. Marcelis LFM, de Visser PHB, Struik PC, Evers JB, editors. Berlin: Springer, pp $13-25$.

Van Noordwijk M, Spek LY, De Willigen P. 1994. Proximal root diameters as predictors of total root system size for fractal branching models. I. Theory. Plant Soil 164:107-118.

Vercambre G, Pagés L, Doussan C, Habib R. 2003. Architectural and synthesis of the plumb tree root system in an orchard using a quantitative modelling approach. Plant Soil 251:1-11.

Wagg JWB. 1967. Origin and development of white spruce rootforms. Departmental publication number 1192, Department of Forestry and Rural Development, Ottawa.

Waisel Y, Eshel A. 2002. Functional diversity of various constituents of a single root system. In: Waisel Y, Eshel A, Kafkafi U, editors. Plant roots: the hidden half. 3rd ed. New York: Marcel Dekker, Inc. pp 157-174.

Wang JR, Letchford T, Comeau P, Kimmins JP. 2000. Aboveand belowground biomass and nutrient distribution of a paper birch and subalpine fir mixed-species stand in the Sub-Boreal Spruce zone of British Columbia. Forest Ecol Manage 130:17-26.

Wang E, Smith CJ. 2004. Modelling the growth and water uptake function of plant root systems: a review. Aust J Agr Res 55:201-523.

Willigen P De, Heinen M, Mollier A, Noordwijk MV. 2002. Twodimensional growth of a root system modelled as a diffusion process. I. Analytical solutions. Plant Soil 240:225-234.

Wirth C, Schumacher J, Schulze E-D. 2004. Generic biomass functions for Norway spruce in Central Europe-a metaanalysis approach toward prediction and encertainty estimation. Tree Physiol 24:121-139.

Wu TH. 2007. Root reinforcement: analysis and experiments. In: Stokes A, Spanos I, Norris J, Cammeraat LH, editors. Bio- and ground eco-engineering: the use of vegetation to improve slope stability. New York, USA: Springer. pp 21-31.

Wu TH, Omber RM, Erb RT, Beal PE. 1988. Study of soil-root interaction. J Geotech Eng 114:1351-1375.

Xiao CW, Yuste JC, Janssens IA, Roskams P, Nachtergale L, Carrara A, Sanchez BY, Ceulemans R. 2003. Above- and belowground biomass and net primary production in a 73year-old Scots pine forest. Tree Physiol 23:505-516.

Zimmermann MH. 1983. Xylem structure and the ascent of sap. New York, USA: Springer-Verlag. 